INNOSC Theranostics and Pharmacological Sciences 2021 Vol. 4 (No. 1) pp: 1-28

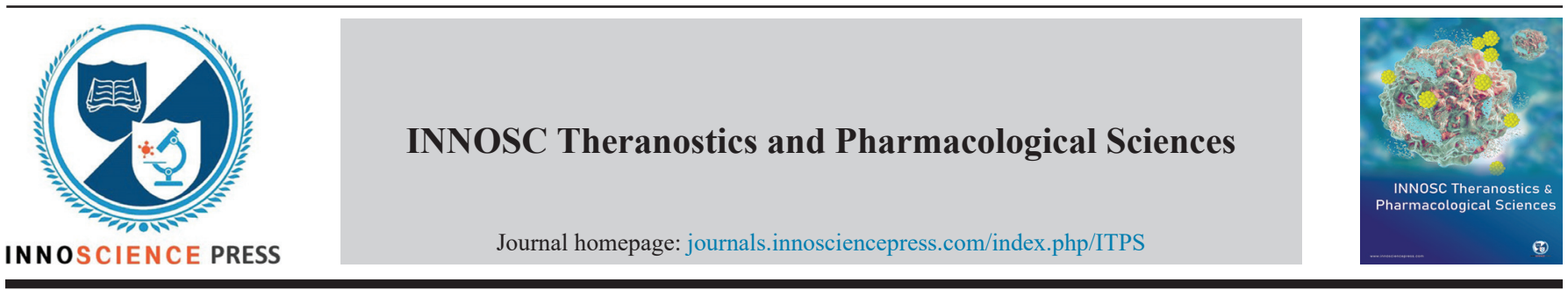

REVIEW ARTICLE

\title{
Coronavirus Disease 2019: An Overview of the Complications and Management
}

\author{
Huimin Shao ${ }^{1 \dagger}$, Hany Sadek Ayoub Ghaly ${ }^{1 \dagger}$, Pegah Varaminin ${ }^{1,2 *}$
}

${ }^{1}$ School of Pharmacy, Faculty of Medicine and Health, The University of Sydney, Sydney, NSW 2006, Australia

${ }^{2}$ Sydney Nano Institute, The University of Sydney, Sydney, NSW 2006, Australia

tThese authors contributed equally to this work.

*Corresponding Author: Dr. Pegah Varamini, Email: pegah.varamini@sydney.edu.au, Tel: +61 28627 0809, Fax: +61293514391

Received: February 3, 2021; Accepted: April 6, 2021; Published: May 3, 2021 DOI: 10.36922/itps.v4i1.1037

Copyright: (c) 2021 Shao, et al. This is an open-access article distributed under the terms of the Attribution NonCommercial 4.0 International 4.0 (CC BY-NC 4.0), which permits all non-commercial use, distribution and reproduction in any medium, provided the original work is properly cited.

\begin{abstract}
:
The severe acute respiratory syndrome coronavirus-2 (SARS-CoV-2) is the causative agent of coronavirus disease 2019 (COVID-19). Since the first report of COVID-19 emerging in Wuhan, China, authorities in 216 countries and territories have reported about 47.3 million COVID-19 cases and 1.2 million deaths. The WHO guidelines for the management of COVID-19 are very limited to recommendations for managing symptoms and advice on careful management of pediatric patients, pregnant women, and patients with underlying comorbidities. There is no approved treatment for COVID-19 and guidelines vary between countries. In this review, first, a brief overview is provided on the basic knowledge about the virus, clinical features of the disease, and different diagnostic methods. Then, the relationship between COVID-19, various body systems, and other complications is discussed. Finallly, different management strategies are discussed, including those drawn on computational chemistry analyses, pre-clinical investigations, and clinical trials which involve pharmacological and non-pharmacological interventions. In conclusion, despite the recent approval of different vaccine candidates, more virological characteristics of SARS-CoV-2 are required to be explored, which may result in the discovery of more potential therapeutic targets leading to safer and more effective treatment to COVID-19.
\end{abstract}

Keywords: Coronavirus disease 2019, Viral infection, Coronavirus, Severe acute respiratory syndrome coronavirus-2, Vaccine, Antiviral agents

\section{Introduction}

The first agent from the beta-coronaviruses' family to infect human beings was severe acute respiratory syndrome coronavirus 1 (SARS-CoV-1). This virus caused an outbreak of the disease called SARS in China in 2003. Another virus from the same family appeared in 2012, called Middle East respiratory syndrome-related coronavirus (MERS-CoV), and it causes the MERS disease [1]. As of April 2020, MERS has taken the lives of 858 persons.
On the same date, SARS-CoV-1 killed 774 people, according to the World Health Organization (WHO). Anew member of the coronaviruses' family emerged in December 2019 in Wuhan, China. This member caused unknown pneumonia cases until January 2020, when the virus was isolated and identified, and it was called SARS-CoV-2. SARS-CoV-2 causes an acute respiratory illness called coronavirus disease 2019 (COVID-19) [2]. SARS-CoV-2 is highly contagious in comparison to SARS-CoV-1 and MERS-CoV. In March 2020, 
the COVID-19 was considered a pandemic by the WHO. SARS-CoV-2, from December 2019 to July 2020, infected 13,049,106 and killed 571,807 as per the WHO. It is evident that COVID-19 is a severe global health issue that should be dealt with wisely and quickly. In this review, we aim to give the readers an overview of COVID-19 in addition to its clinical features, diagnosis, complications, and relationship to comorbidities. A section of this article discusses different strategies toward the management of the disease, including results from computational chemistry analysis, pre-clinical investigations, and clinical trials.

SARS-CoV-2 belongs to the same family as SARS-CoV-1 and MERS-CoV, which is beta-coronavirus lineage $\beta$. SARS-CoV-2 is an enveloped virus with a single positively-charged RNA genome. Its particle is round or oval and has a diameter range of $60-140 \mathrm{~nm}$ [3]. It has the following genome structure: 5'UTR-ORF1aORF1b-S gene-E gene-M gene-N gene-3'UTR. $\mathrm{S}$ gene codes for the spike (S) protein, which is an essential surface protein on the viral cell responsible for interacting with host cell surface receptors (mainly angiotensin-converting enzyme 2 or [ACE2]) for viral entry into host cells. The M protein is essential for nutrients transport across the cell membrane, E protein for viral release from the host cells, and $\mathrm{N}$ protein for maintaining genome stability [4].

COVID-19 is the severe acute respiratory syndrome caused by SARS-CoV-2 infections. Symptoms of COVID-19 include fever, dry cough, fatigue, nausea, and diarrhea. SARS-CoV-2 spreads from the bronchi to the alveoli and then to other body organs causing acute respiratory distress syndrome (ARDS), acute cardiac injury, acute kidney injury (AKI), secondary bacterial infection, and shock, and it may lead to death in some cases [5,6]. In addition to direct organ failure caused by SARS-CoV-2, it also induces a robust inflammatory response in the lungs, which results in lung injury. This inflammatory response is accompanied by very high levels of cytokines, including interleukin (IL)-1 $\beta$, IL-6, IL-12, and interferon (IFN)- $\gamma[7]$.

SARS-CoV-2 is transferred among human beings mainly by droplets. However, its RNA was found in the feces of some patients indicating that live viruses may be present in the feces, which means that another route for viral transfer between people may be present [8].

Several studies indicated that men are more affected by COVID-19 than women $[2,6]$. More severe illness is present in those with comorbidities such as diabetes, cardiovascular diseases, hypertension, and malignancy. Blood tests show significant changes in the levels of circulating molecules. Different studies showed different fatality rates for COVID-19, but generally speaking, it is between 2.5 and 5.5\% [2,6,9]. The mortality rate is affected by age, comorbidities, and probably genetic differences [6].

This review briefly discusses some clinical features of COVID-19, current diagnostic methods and different complications caused by the disease. Moreover, we described computational studies that refer to some existing compounds as potential agents against SARS-CoV-2, such as didanosine, remdesivir, IDX-184, itacitinib, and adeflavin. The pre-clinical trials' section provides an insight into the efficacy of some existing compounds under investigation against SARS-CoV-2, in addition to their efficacy against MERS-CoV and SARS-CoV-1 as an indication of their potential efficacy against SARS-CoV-2. We highlighted the roles of chloroquine (CQ), hydroxychloroquine (HCQ), and remdesivir as potential agents against COVID-19. Finally, the clinical trials' section summarizes results from clinical trials testing different agents against COVID-19. In this review, we mainly focused on those agents used to treat, in addition to agents used to manage COVID-19.

\section{Clinical features}

Zhut et al. analyzed 38 large studies, including 3062 patients, to identify the clinical features of COVID-19 [2]. The results are summarized in Tables 1. Studies show that more men get affected by COVID-19 than women, as 56.9\% of COVID-19 patients are men while $43.1 \%$ of the patients are women.

\subsection{Presentations}

The presentation of COVID-19 varies among different people at illness onset, but most patients 
Table 1. Clinical signs and symptoms, laboratory, and imaging indicators [2]

\begin{tabular}{lc}
\hline \multicolumn{2}{c}{ Clinical signs and symptoms } \\
\hline Symptom & $\begin{array}{c}\text { Percentage of } \\
\text { patients }\end{array}$ \\
\hline Fever & 80.40 \\
Cough & 63.10 \\
Fatigue & 46 \\
Expectoration & 41.80 \\
Anorexia & 38.80 \\
Chest tightness & 35.70 \\
Shortness of breath & 35 \\
Dyspnea & 33.90 \\
Muscle soreness & 33 \\
Headache & 15.40 \\
Pharyngalgia & 13.10 \\
Diarrhea & 12.90 \\
Asymptomatic patients & 11.90 \\
Shivering & 10.90 \\
Nausea or vomiting & 10.20 \\
Abdominal pain & 4.40 \\
Laboratory indicators & \\
Indicator & \\
Normal leucocytes count & \\
Lymphopenia & \\
Elevated C-reactive protein & 6.5 \\
Elevated erythrocyte sedimentation rate & 65.6 \\
Decreased oxygenation index & 63.6 \\
Abnormal liver functions & 29.8 \\
Abnormal renal functions & 25.5 \\
Abnormal D-dimer & 25.9 \\
Leukocytosis & 12.6 \\
Elevated procalcitonin & 17.5 \\
Imaging results & \\
Unilateral lung lesion & of patients \\
Bilateral lung lesion & \\
Morcentage of patients with ARDS & \\
\hline
\end{tabular}

experience some common signs and symptoms during the course of the disease. These include fever or chills, cough, shortness of breath or difficulty breathing, fatigue, muscle or body aches, headache, new loss of taste or smell, sore throat, congestion or runny nose, nausea or vomiting, and diarrhea. Table 1 shows signs and symptoms observed in most COVID-19 patients, with the percentages of patients experiencing each symptom. It demonstrates that fever, cough, and fatigue were among the most common symptoms, while nausea, vomiting, and diarrhea were the most common symptoms affecting the digestive system.

\subsection{Blood test abnormalities}

Table 1 depicts the most common abnormalities in the blood test results in COVID-19 patients. It is essential to highlight that inflammatory indicators are high in most patients. Besides, liver and kidney function tests are abnormal in some patients. This table also shows that most of the COVID-19 patients get bilateral lung lesions and lastly, the patients have a mortality rate of $5.5 \%$.

\section{Diagnosis}

\subsection{Reverse transcription-polymerase chain reaction $(R T-P C R)$}

According to the Diagnosis and Treatment Protocol for Novel Coronavirus Pneumonia (Trial Version 8) issued by the National Health Commission and State Administration of Traditional Chinese Medicine on August 19, 2020, real-time fluorescence RT-PCR detection of new coronavirus nucleic acid or the fact that the viral gene sequence is highly homologous to the known novel coronaviruses can be regarded as the standard of the clinical diagnosis of COVID-19. The new coronavirus RNA can be detected in nasopharyngeal swabs, sputum, lower respiratory tract secretions, blood, and feces. RTPCR might show a false-negative detection rate at about $30-50 \%$ because of sampling position and possible low load of virus (e.g., the virus is not at the replication phase at the time of detection). Hence, it is recommended to obtain specimens from the lower respiratory tract, such as sputum and air tract extraction, to increase the accuracy of RT-PCR tests [10]. However, RT-PCR is time consuming and has a complex confirmation process. Sometimes it needs a second test after 24 $\mathrm{h}$ if the first sample taking from both throat and lower respiratory tract is negative [11]. 


\subsection{Computed tomography (CT)}

$\mathrm{CT}$ is another vital tool in the diagnosis of COVID-19. It is easy to perform, and a scan takes only $5 \mathrm{~s}$. Furthermore, it decreases the possibility of medical staff exposure to the virus. Several indicators, such as small subpleural ground-glass opacities (GGO), are essential in the diagnosis of asymptomatic patients [12].

\subsection{Serological chemiluminescence immunoassay (CLIA)}

As both Immunoglobulin $\mathrm{M}$ (IgM) and $\operatorname{IgG}$ play important roles in long-term immunity and immunological memory, serological detection of $\operatorname{IgM}$ and $\operatorname{IgG}$ can be another potential way to diagnose COVID-19 [13]. According to the Diagnosis and Treatment Protocol for Novel Coronavirus Pneumonia (Trial Version 8) issued by the National Health Commission and State Administration of Traditional Chinese Medicine on August 19, 2020, if the novel coronavirus-specific IgM and IgG are detected in serum, and, compared to the acute phase, the titration of the novel coronavirus specific IgG reaches at least 4-fold increase during convalescence, suspected cases can be diagnosed as COVID-19 [10].

\section{Complications of COVID-19}

Yang et al. investigated the cause of death in 92 patients who died from COVID-19 [1]. Results showed that $79.3 \%$ of deceased patients died because of ARDS. About 7.6\% died of septic shock. Myocardial infarction was the cause of death in $6.5 \%$ of patients, followed by heart failure (2.2\%), multiple organ dysfunction syndrome (MODS) $(2.2 \%)$, and pneumothorax (1.1\%). Inflammatory markers such as procalcitonin, C-reactive protein, and serum amyloid A were significantly high in 39 patients. Thirty-one patients had abnormally high myocardial enzymes during hospitalization. Only 15 cases had an abnormal liver function or total bilirubin. The acute renal injury occurred in 14 patients. Furthermore, 14 patients experienced MODS. It is suggested by the authors that the hyper-inflammatory condition (including cytokine storm) caused by SARS-CoV-2 may be responsible for these complications in addition to direct viral damage to host cells, especially cells with high
ACE2 expression such as lung cells, bile duct cells, and renal tubules.

\subsection{Impact of COVID-19 on renin angiotensin (Ag) aldosterone system (RAAS)}

The RAAS starts with renin cleaving angiotensinogen to $\mathrm{Ag} 1$ which is further cleaved by $\mathrm{ACE}$ to $\mathrm{Ag} 2$. Ag II binds to Ag II receptors 1 and 2 [14].

ACE2 is mainly present in the lungs and small intestines and it converts $\mathrm{Ag}$ II to $\mathrm{Ag}(1-7)$, which binds to Mas receptor producing anti-inflammatory and anti-fibrinolytic activities. On the other hand, activation of Ag II receptors by Ag II results in proinflammatory and pro-fibrinolytic activities [14]. As discussed earlier, ACE2 is the main host receptor responsible for the internalization of SARS-CoV-2 through interaction with the $\mathrm{S}$ protein on the viral cell surface [4].

The binding of SARS-CoV-2 to ACE2 causes exhaustion of ACE2. A study showed that the loss of ACE2 expression causes severe lung injury [15]. Moreover, injecting mice with recombinant human ACE2 protein resulted in a decrease in acute lung injury expressed by increased lung elasticity and reduced pulmonary edema formation. On the other side, Ag II level was extremely high in the serum of COVID-19 patients due to the S protein, as confirmed by two studies [16,17]. High Ag II levels resulted in severe acute lung injury and pulmonary edema while blocking of Ag II receptor 1 by a specific inhibitor decreased lung injury and edema in mice $[16,17]$.

Ag-converting enzyme inhibitors (ACEI) and $\mathrm{Ag}$ II receptor blockers (ARBs) represent two classes of medications widely used in the management of cardiovascular diseases. AECIs act by reducing the production of $\mathrm{Ag}$ II through inhibition of ACE while ARBs directly block Ag II receptors [14]. It is proposed now that ACEI/ARBs can reduce lung injury caused by SARS-CoV-2 through their mechanisms of action that attenuate Ag II action [14].

Another point of view proposed by some researchers include that blocking of ACE by ACEI or blocking of $\mathrm{Ag}$ II receptor by ARBs can lead to overexpression of ACE2, which may increase the invasion of SARSCoV-2 to host cells [18,19]. Furthermore, 
$\mathrm{N}$-(2-Aminoethyl)-1-aziridineethanamine, which is an experimental ACE2 inhibitor, was investigated for its use in treating cardiovascular disease and its activity against SARS. This agent is now being investigated to help reduce host cell invasion by SARS-CoV-2 [20]. Clinical trials are needed to investigate whether ACEI/ARBs are beneficial in reducing the mortality rate in COVID-19 patients or not.

\subsection{Impact of COVID-19 on the cardiovascular system}

According to the $\mathrm{WHO}$, cardiovascular patients have worse outcomes from SARS-CoV-2 infections with an increase in mortality rate by $5-10$ folds. COVID-19 causes death in $10.5 \%$ of patients with cardiovascular complications and $6 \%$ of hypertensive patients [21].

Cardiovascular patients are more liable to get viral illness and are at high risk of developing cardiovascular events during or after a viral infection. For example, acute myocardial infarction is common in cardiovascular patients following influenza infection [22]. In one study in China, $32.7 \%$ of hypertensive patients got severe COVID-19 in comparison to $12.6 \%$ of non-hypertensive patients [9]. Around $33.9 \%$ of COVID-19 patients with cardiovascular diseases had a severe illness in comparison to $15.3 \%$ of COVID-19 patients without cardiovascular disease. In the same study, 22\% of COVID-19 patients with cardiovascular diseases reached the endpoint (death or admission to intensive care unit [ICU] or need for invasive ventilation) compared to only $7.7 \%$ of COVID-19 non-cardiovascular patients. In hypertensive patients with COVID-19, $19.7 \%$ reached the endpoint compared to $5.9 \%$ in non-hypertensive patients [9]. On the other hand, SARS-CoV-2 infection can lead to cardiovascular complications, as discussed earlier.

While SARS-CoV-1 can replicate in the hearts of $35 \%$ of patients, it is still unknown whether SARS-CoV-2 can do the same [23]. This leads to the possibility that the main reason for cardiovascular complications in COVID-19 patients is the hyperinflammatory condition caused by SARS-CoV-2 in addition to the loss of circulating ACE2 in myocardial tissue (as an immune response to decrease viral replication), which increases the probability for heart failure. Furthermore, the high level of Ag II leads to hypertension and thrombosis. The release of troponin to the blood is the main sign of myocardial injury caused by SARS-CoV-2 [24].

\subsection{COVID-19 and metabolic diseases}

It is well known that diabetic patients are more prone to viral and bacterial respiratory tract infections [25]. In diabetic patients infected with SARS-CoV-1, hyperglycemia was associated with a high mortality rate which may increase by up to 3-folds in response to hyperglycemia [26,27]. A study on MERS Saudi patients showed that diabetes was strongly associated with a high rate of mortality [28].

Regarding SARS-CoV-2, type 2 diabetic patients suffered from more severe illness of COVID-19 in comparison to non-diabetic patients. This was assessed by blood counts, coagulation parameters and inflammation biomarkers [29]. In the USA, about $32 \%$ of COVID-19 patients in the ICU had diabetes mellitus, $24 \%$ of COVID-19 patients in the hospital but not in the ICU had diabetes, and only $6 \%$ of non-hospitalized patients had diabetes which clearly shows that diabetes was associated with poorer prognosis of SARS-CoV-2 infection [30].

On the otherhand, viral respiratory tractinfections and the medications used, such as glucocorticoids, lead to impaired insulin sensitivity which requires adjusting the doses of glucose-lowering agents. In addition, viral respiratory tract infections lead to an increase in mortality rate in diabetic patients [31]. In severe cases, SARS-CoV-2 causes liver injury and higher blood glucose levels [32].

Obesity is also related to more severe SARSCoV-2 illness [33].

\subsection{COVID-19 and venous thromboembolism (VTE)}

Patients hospitalized due to COVID-19 are at high risk of VTE [34]. Heparins, especially enoxaparin, were used in one study to reduce the risk for VTE in COVID-19 patients, and they resulted in reducing the mortality in those patients by reducing sepsisinduced coagulopathy [35]. It was hypothesized that in some COVID-19 patients not treated with heparins, the mortality rate was high because they developed pulmonary embolism [34]. 


\subsection{COVID-19 and anxiety/depression}

One study indicated that $47.4 \%$ of COVID-19 patients suffered from anxiety, and $30.3 \%$ of patients suffered from depression [36]. Female patients are more likely to suffer from anxiety/depression than male patients. The study also showed that nonpatients with contact history to epidemic areas are more likely to suffer from anxiety/depression. The authors recommend psychological evaluation of confirmed or suspected patients and taking all the necessary interventions, including pharmacological treatment, into account [33].

\subsection{COVID-19 and kidney disease}

AKI is common in COVID-19 patients in the ICU, with an incidence of $15 \%$. Since renal tubules' cells have a high expression of ACE2, SARS-CoV-2 can cause direct damage to these cells in addition to the damage caused by the cytokine storm induced by the virus. On the other hand, chronic kidney disease (CKD) is associated with more severe COVID-19 infections. The mortality rate because of pneumonia in CKD patients is $14-16$ times higher than that in the general population [37].

\subsection{Impact of COVID-19 on the digestive system and liver}

As discussed earlier, SARS-CoV-2 infection can adversely affect the digestive system causing symptoms such as nausea, vomiting, diarrhea, and abdominal pain. In addition, about $14.8-53.1 \%$ of COVID-19 patients experience high levels of liver enzymes in the blood. Viral RNA was detected in the feces of COVID-19 patients even after the clearance of the virus from the upper respiratory tract [38].

\subsection{Management of COVID-19}

In this section, we highlighted the results from computational studies, pre-clinical trials, and clinical trials in the management of COVID-19.

\subsection{Results from computational chemistry studies}

Several studies were published with the aim of identifying potential targets in SARS-CoV-2 and medications that may work against the virus using computer-based techniques. We summarize in this article some of these studies to highlight some potential anti-SARS-CoV-2 agents that might be worth further investigation. In one study, scientists used computer-based technology to identify host genes that may be related to SARS-CoV-2 activity as well as agents that affect these genes. The most important genes include HSPA4, ILK, and MDM2. The authors suggested that the possible effective drugs may include nimesulide (a cyclooxygenase 2 inhibitor), fluticasone propionate (corticosteroid), thiabendazole (antifungal and anti-inflammatory), and didanosine (targets both adenosine kinase and IL-2 receptor antagonist [IL2RA]). The authors highlighted the role of didanosine with the hypothesis that blocking IL2RA by didanosine may reduce fatality in COVID-19. The hypothesis is on the basis that the hypersecretion of IL-1RA in Ebola virus infection was associated with high fatality. The same results were reported that IL2RA is hypersecreted in SARS-CoV-2, and hence, it may be associated with fatality rate [39].

Using docking software, Abdo Elfiky tested the affinity of 24 compounds to SARS-CoV-2 RNA-dependent RNA polymerase [40]. This is a very important enzyme in the lifecycle of most RNases. Five FDA-approved compounds showed tight binding to the enzyme. These compounds are galidesivir, remdesivir, tenofovir, sofosbuvir, and ribavirin with binding energy values of -7.0 , $-7.6,-6.9,-7.5$, and $-7.8 \mathrm{Kcal} / \mathrm{mol}$, respectively. Setrobuvir, IDX-184 and YAK had binding energy values to the enzyme of $-9.3,-9.0$, and $-8.4 \mathrm{Kcal} /$ mol, respectively, suggesting that they bind strongly to the enzyme. The author highlighted IDX-184 because it had a high binding affinity with an interaction pattern very similar to the physiological nucleotide (Guanosine-5'-triphosphate) which has the strongest binding affinity to the enzyme between all nucleotides.

Other researchers built a computational model of SARS-CoV-2 S protein and examined the binding affinity of several compounds to it as well as 3CLpro main protease. As for S protein, coenzyme A, adeflavin, tiludronate, and iomeprol had the highest binding affinities with binding energy values of $-11.55,-11.08,-9.36$, and -7.68 , respectively [41]. Regarding 3CLpro protease, nicotinamide adenine dinucleotide + hydrogen (NADH) had the highest binding affinity with an 
energy value of -11.016 , followed by adeflavin $(-10.339)$, cangrelor $(-10.269)$, carfilzomib $(-8.924)$, and zanamivir $(-8.843)$. The SARS$\mathrm{CoV}-2$ 3CLpro main protease was studied in another computational study and some potential inhibitors were identified using SCAR protocol [42]. Among the potential inhibitors is itacitinib which had the highest docking score $(-9.0)$, followed by oberadilol (-8.9), telcagepant $(-8.8)$, vidupiprant $(-8.7)$, and pilaralisib $(-8.5)$ [41].

\subsection{Results from pre-clinical trials and clinical trials}

\subsubsection{Antivirals: $\mathrm{CQ} / \mathrm{HCQ}$}

CQ and HCQ are used mainly in the prevention and treatment of malaria in addition to the management of chronic inflammatory diseases such as rheumatoid arthritis and systemic lupus erythematosus [43]. However, these agents may play a role in the treatment of COVID-19. The proposed mechanism of action includes two parts. The antiviral part includes interfering with the entry of SARS-CoV-2 into host cells by inhibiting glycosylation of host ACE2 receptors and proteolytic processing in addition to elevating endosomal and lysosomal $\mathrm{pH}$. The immunomodulatory mechanism is through the reduction of cytokine production and decrease of autophagy in the host cells [44,45]. An in vitro study showed that the EC50 of CQ against SARSCoV-2 was $5.47 \mu \mathrm{M}$ while that of HCQ was $0.72 \mu \mathrm{M}$ suggesting that HCQ was 7.6 times more potent than CQ [46]. Conversely, the EC50 values of CQ and HCQ against SARS-CoV-1 were determined to be $6.5 \mu \mathrm{M}$ and $34 \mu \mathrm{M}$, respectively, indicating that CQ was 5 times as potent as HCQ [47].

Two in vitro studies examined the efficacy of CQ and HCQ against SARS-CoV-2 at a multiplicity of infection values. At infection values of $0.01,0.02$, 0.2, and 0.8, CQ had EC50 values of 2.71, 3.81, 7.14, and 7.36 $\mu \mathrm{M}$, respectively, while HCQ had EC50 values of 4.51, 4.06, 17.31, and $12.96 \mu \mathrm{M}$, respectively $[48,49]$.

According to a French study, compared to $12.5 \%$ in the control group, $70 \%$ of the HCQ treated patients were virologically cured at day 6 post-inclusion $(p=0.001)$. Furthermore, at day 6 post-inclusion, a comparison among the effect of HCQ as a single treatment, HCQ, and azithromycin in combination and control showed that the percentage of patients who were virologically cured was $57.1 \%, 100 \%$, and $12.5 \%$ in treatment groups, respectively, $(p<0.001)$ which indicated azithromycin plus HCQ could exert a synergistic effect. In addition, this study pointed out that HCQ was significantly more efficient among patients with symptoms of upper respiratory tract infection and lower respiratory tract infections compared to asymptomatic ones $(p<0.05)$ [50]. A Chinese study showed that CQ phosphate could inhibit the exacerbation of pneumonia, promote a virus-negative transformation, improve lung imaging, and shorten the course of the disease. During the treatment of more than 100 patients involved, no severe adverse effect was found [51]. A case in Colombia illustrated that the use of CQ (orally $300 \mathrm{mg}$, base, q12h) and clarithromycin (intravenous 500 $\mathrm{mg}$ q12h) could successfully relieve the symptoms, and the patient was discharged after 5 days of treatment [52]. In an open-label, randomized controlled trial (ChiCTR2000029868), 75 patients were given standard of care, including intravenous fluids, supplemental oxygen, regular laboratory testing, SARS-CoV testing, hemodynamic monitoring, and intensive care as control, while the other 75 patients were given standard of care plus HCQ. The result was that among the patients, who received standard of care, 56 patients became virologically negative and 19 patients remained positive, while 53 patients became negative and 22 remained positive among the patients who received standard of care plus HCQ. By day 28, the percentage of negative conversion was $85.4 \%$ and $81.3 \%$ in the standard of care plus HCQ group and control group, respectively, which indicated that the application of HQC did not significantly contribute to the negative conversion compare to the standard of care only. In addition, the adverse reactions occurrence rate was higher in HCQ group (30\%) compared to the control group (10\%) [53]. A study showed that the creatine phosphokinase (CK) levels (an indicator of CQ adverse effect) were higher in the group that received a high dose of CQ (7 out of $14[50 \%])$ compared to the one administered a low dose (6 out of 19 [13.6\%]) in patients with severe conditions. These results suggested that high doses of CQ are not recommended in the treatment of severely ill patients for its potential adverse 
effects [54]. It is of great significance to monitor the serum electrolytes, blood glucose, hepatic, renal functions, body temperature, respiratory symptoms, and lung imaging [55]. Moreover, a baseline electrocardiogram should be established because both CQ and HCQ have the potential to prolong the corrected QT interval [56]. Other relevant clinical trials are shown in Table 2.

\subsubsection{Antivirals: Remdesivir}

Remdesivir was originally developed to fight against RNA viruses such as Coronaviridae and Flaviviridae. One in vitro study showed that remdesivir has antiviral activity against SARS-CoV-2 with EC50 of $0.77 \mu \mathrm{M}$ and EC90 of $1.76 \mu \mathrm{M}$ in addition to CC50 $>100 \mu \mathrm{M}$ [48]. The low EC50 that remdesivir possesses, in addition to a good safety profile and high selectivity against viral RNA-dependent RNA polymerase, makes it a potential treatment for COVID-19. Shehan et al. added to these properties that SARS-CoV-1 did not develop resistance to remdesivir in addition to the long half-life of remdesivir that allows for oncedaily dosing [57]. The EC50 of remdesivir against SARS-CoV-1 and MERS-CoV was investigated and was found to be around $0.07 \mu \mathrm{M}[48,58]$. Remdesivir was tested in vitro against the Ebola virus where it showed good inhibition of viral replication in addition to decreasing the severity of symptoms from the disease [59]. Similar results were reported in MERS-CoV [60]. The earlier the remdesivir is used, the better the treatment outcome $[57,60]$.

In a randomized, double-blind, placebocontrolled, multicenter trial (NCT04257656), remdesivir was given to 158 patients intravenously (200 $\mathrm{mg}$ on day $1,100 \mathrm{mg}$ on days $2-10 \mathrm{in}$ single daily infusions) while other 78 patients received placebo (the same volume infusions for 10 days in total) as the control group. The patients in the treatment group (median 18.0 days) improved clinically faster than those in the control group (23.0 days). The rates of improvement in the remdesivir group on days 14 and 28 were numerally higher compared to the control group. Furthermore, the 28-day mortality of the remdesivir group was lower than that of the control group. The decrease in the viral load over time was not significantly different in the two groups. However, all three outcomes, including the time to clinical improvement, mortality, or time to clear the virus, were not statistically different compared to placebo among severely ill COVID-19 patients [61]. In another open-label study, remdesivir was given to 35 patients intravenously $(200 \mathrm{mg}$ on day 1 and $100 \mathrm{mg}$ on days $2-10$ ). Among these 35 patients, 18 patients started the remdesivir treatment in the ICU and 17 in the infectious disease ward (IDW). Only $21(63 \%)$ patients finished the drug schedule while nine patients in ICU and four patients in IDW stopped because of adverse events $(8,22.8 \%)$, death $(4,11.4 \%)$, and early discharge $(1,2.9 \%)$ after a median of 5 doses. By day 10 , four (22.2\%) of the ICU patients showed improvement, ten $(55.5 \%)$ still needed invasive ventilation, and four $(22.2 \%)$ had died. Among the IDW patients, six patients $(35.3 \%)$ showed improvement in the hospitalization status, ten (58.8\%) still needed high-flow therapy or non-invasive ventilation; one had died (5.8\%). As only one of the IDW patients worsened in the hospitalization condition during the follow-up 28 days, remdesivir is possibly more efficacious among early, non-critical patients. The most frequent severe adverse events were hypertransminasemia (42.8\%) and AKI (22.8\%) [62]. The safety and efficacy of remdesivir need to be further studied as one of the most likely antiviral drugs to cure COVID-19. Related clinical trials are shown in Table 2.

\subsubsection{Antivirals: Umifenovir}

Umifenovir is an antiviral agent against influenza approved in Russia and China. An in vitro study showed that umifenovir has activity against SARS-CoV-1 by targeting the S protein/ACE2 interaction and hence decreased the fusion of the viral cell to the cell membrane. An in vitro study showed that umifenovir effectively inhibited SARS$\mathrm{CoV}-2$ at a concentration of $10-30 \mu \mathrm{M} / \mathrm{L}$ [63].

A study involving 50 patients including Lopinavir/ Ritonavir (LPV/r) group (34 patients receiving $400 \mathrm{mg} / 100 \mathrm{mg}$ of LPV/r, bid) and arbidol group (16 patients receiving $0.2 \mathrm{~g}$ of arbidol, 3 times/day, 7 days) indicated that after 14 days of treatment, all cases in arbidol group turned virologically negative while 15 cases (44.1\%) in LPV/r group remained positive in RNA test. Furthermore, this report showed that the course of the disease was 
Table 2. Ongoing clinical trials with antiviral drugs for COVID-19 as of October 26, 2020 [71,83]

\begin{tabular}{|c|c|c|c|c|}
\hline $\begin{array}{l}\text { NCT/registration } \\
\text { number }\end{array}$ & Title & Intervention/comparator & $\begin{array}{l}\text { Recruitment } \\
\text { status }\end{array}$ & Phase \\
\hline NCT04362332 & $\begin{array}{l}\text { Chloroquine, hydroxychloroquine } \\
\text { or only supportive care in patients } \\
\text { admitted with moderate to severe } \\
\text { COVID-19 (ARCHAIC) }\end{array}$ & $\begin{array}{l}\text { Chloroquine or } \mathrm{HQC}+\text { supportive } \\
\text { care/supportive care }\end{array}$ & Terminated & IV \\
\hline NCT04331600 & $\begin{array}{l}\text { Chloroquine as antiviral treatment } \\
\text { in coronavirus infection } 2020 \\
\text { (QUARANTINE2020) }\end{array}$ & $\begin{array}{l}\text { Standard of care+chloroquine } \\
\text { phosphate+telemedical approach/ } \\
\text { standard of care+telemedical } \\
\text { approach. }\end{array}$ & Recruiting & IV \\
\hline NCT04351191 & $\begin{array}{l}\text { Prophylaxis of exposed COVID-19 } \\
\text { individuals with mild symptoms } \\
\text { using chloroquine compounds } \\
\text { (PRECISE) }\end{array}$ & $\begin{array}{l}\text { Chloroquine or } \mathrm{HQC}+\text { standard } \\
\text { care/standard care+placebo }\end{array}$ & Recruiting & IV \\
\hline NCT04346667 & $\begin{array}{l}\text { Post-exposure prophylaxis for } \\
\text { asymptomatic SARS-CoV-2 } \\
\text { COVID-19 patients with chloroquine } \\
\text { compounds (PEACE) }\end{array}$ & $\begin{array}{l}\text { Chloroquine or } \mathrm{HQC}+\text { standard } \\
\text { care/standard care+ }+ \text { placebo }\end{array}$ & Recruiting & IV \\
\hline NCT04363866 & $\begin{array}{l}\text { A pilot study to assess } \\
\text { hydroxychloroquine in patients with } \\
\text { SARS-CoV-2 (COVID-19) }\end{array}$ & HQC/placebo & $\begin{array}{l}\text { Not yet } \\
\text { recruiting }\end{array}$ & IV \\
\hline NCT04316377 & $\begin{array}{l}\text { Norwegian coronavirus disease } 2019 \\
\text { study (no COVID-19) }\end{array}$ & HQC+standard care/standard care & $\begin{array}{l}\text { Active, not } \\
\text { recruiting }\end{array}$ & IV \\
\hline NCT04330495 & $\begin{array}{l}\text { Randomized, controlled, double-blind } \\
\text { clinical trial comparing the efficacy } \\
\text { and safety of chemoprophylaxis } \\
\text { with hydroxychloroquine in patients } \\
\text { under biological treatment and/or } \\
\text { jak inhibitors in the prevention of } \\
\text { SARS-CoV-2 infection }\end{array}$ & HQC/placebo & $\begin{array}{l}\text { Not yet } \\
\text { recruiting }\end{array}$ & IV \\
\hline NCT04334967 & $\begin{array}{l}\text { Hydroxychloroquine in patients } \\
\text { with newly diagnosed COVID-19 } \\
\text { compared to standard of care }\end{array}$ & HQC/vitamin c & Suspended & IV \\
\hline NCT04384380 & $\begin{array}{l}\text { Efficacy and tolerability of } \\
\text { hydroxychloroquine in adult patients } \\
\text { with COVID-19 }\end{array}$ & HQC sulphate/standard care & Recruiting & IV \\
\hline NCT04382625 & $\begin{array}{l}\text { Hydroxychloroquine in SARS-CoV-2 } \\
\text { (COVID-19) pneumonia trial }\end{array}$ & HQC/standard care & $\begin{array}{l}\text { Not yet } \\
\text { recruiting }\end{array}$ & IV \\
\hline NCT04429867 & $\begin{array}{l}\text { Hydroxychloroquine Use in } \\
\text { hospitalized patients with COVID-19: } \\
\text { impact on progression to severe or } \\
\text { critical disease }\end{array}$ & HQC/placebo & $\begin{array}{l}\text { Active, not } \\
\text { recruiting }\end{array}$ & IV \\
\hline NCT04466540 & $\begin{array}{l}\text { Randomized placebo-controlled trial } \\
\text { of hydroxychloroquine in outpatient } \\
\text { cases with coronavirus disease } 2019 \\
\text { (COVID-19) (COALITION-V) }\end{array}$ & HQC/placebo & Recruiting & IV \\
\hline ChiCTR2000029992 & $\begin{array}{l}\text { An open randomized controlled } \\
\text { trial for chloroquine phosphate and } \\
\text { hydroxychloroquine sulphate in the } \\
\text { treatment of severe novel coronavirus } \\
\text { pneumonia (COVID-19) }\end{array}$ & $\begin{array}{l}\text { Chloroquine phosphate or HQC } \\
\text { sulfate/routine treatment }\end{array}$ & $\begin{array}{l}\text { Not yet } \\
\text { recruiting }\end{array}$ & IV \\
\hline
\end{tabular}


Table 2. (Continued)

\begin{tabular}{|c|c|c|c|c|}
\hline $\begin{array}{l}\text { NCT/registration } \\
\text { number }\end{array}$ & Title & Intervention/comparator & $\begin{array}{l}\text { Recruitment } \\
\text { status }\end{array}$ & Phase \\
\hline ChiCTR2000029899 & $\begin{array}{l}\text { Evaluation the efficacy and safety } \\
\text { of hydroxychloroquine sulfate } \\
\text { in comparison with phosphate } \\
\text { chloroquine in mild and common } \\
\text { patients with novel coronavirus } \\
\text { pneumonia (COVID-19) a } \\
\text { randomized, open-label, parallel, } \\
\text { controlled trial }\end{array}$ & $\begin{array}{l}\text { Chloroquine phosphate or HQC } \\
\text { sulfate/blank }\end{array}$ & Recruiting & IV \\
\hline ChiCTR2000029868 & $\begin{array}{l}\text { Hydroxychloroquine treating novel } \\
\text { coronavirus pneumonia (COVID-19) } \\
\text { a randomized controlled, open label, } \\
\text { multicenter trial }\end{array}$ & HQC sulfate/conventional treatment & Completed & IV \\
\hline ChiCTR2000032487 & $\begin{array}{l}\text { Study for using sulfate in the } \\
\text { prevention and control of novel } \\
\text { coronavirus pneumonia (COVID-19) } \\
\text { in high and low prevalence } \\
\text { communities }\end{array}$ & HQC sulfate/placebo & $\begin{array}{l}\text { Not yet } \\
\text { recruiting }\end{array}$ & IV \\
\hline ChiCTR2000030718 & $\begin{array}{l}\text { Randomized controlled trial for } \\
\text { Chloroquine Phosphate in the } \\
\text { Treatment of novel coronavirus } \\
\text { pneumonia (COVID-19) }\end{array}$ & Chloroquine phosphate/blank & Recruiting & IV \\
\hline ChiCTR2000029559 & $\begin{array}{l}\text { Therapeutic effect of } \\
\text { hydroxychloroquine on novel } \\
\text { coronavirus pneumonia (COVID-19) }\end{array}$ & HQC/placebo & Recruiting & IV \\
\hline NCT04255017 & $\begin{array}{l}\text { A prospective/retrospective, } \\
\text { randomized controlled clinical study } \\
\text { of antiviral therapy in the } 2019-\mathrm{nCoV} \\
\text { pneumonia }\end{array}$ & $\begin{array}{l}\text { Lopinavir-ritonavir/supportive } \\
\text { treatment }\end{array}$ & Recruiting & IV \\
\hline NCT02735707 & $\begin{array}{l}\text { Randomized, embedded, } \\
\text { multifactorial adaptive platform trial } \\
\text { for community- acquired pneumonia } \\
\text { (remap-cap) }\end{array}$ & Lopinavir-ritonavir/blank & Recruiting & IV \\
\hline NCT04255017 & $\begin{array}{l}\text { A prospective/retrospective, } \\
\text { randomized controlled clinical study } \\
\text { of antiviral therapy in the } 2019-\mathrm{nCoV} \\
\text { pneumonia }\end{array}$ & $\begin{array}{l}\text { Lopinavir -ritonavir+symptomatic } \\
\text { supportive treatment/symptomatic } \\
\text { supportive treatment }\end{array}$ & Recruiting & IV \\
\hline NCT04286503 & $\begin{array}{l}\text { The clinical study of carrimycin on } \\
\text { treatment patients with COVID-19 }\end{array}$ & Lopinavir/ritonavir/basic treatment & $\begin{array}{l}\text { Not yet } \\
\text { recruiting }\end{array}$ & IV \\
\hline ChiCTR2000029741 & $\begin{array}{l}\text { Efficacy of chloroquine and lopinavir/ } \\
\text { ritonavir in mild/general novel } \\
\text { coronavirus (COVID-19) infections a } \\
\text { prospective, open-label, multicenter } \\
\text { randomized controlled clinical study }\end{array}$ & $\begin{array}{l}\text { Chloroquine phosphate/lopinavir } \\
\text {-ritonavir }\end{array}$ & Recruiting & IV \\
\hline NCT04350684 & $\begin{array}{l}\text { Umifenovir in hospitalized } \\
\text { COVID-19 patients (UAIIC) }\end{array}$ & $\begin{array}{l}\text { Umifenovir+interferon }-\beta 1 \mathrm{a}+\mathrm{lpv} / \\
\mathrm{r}+\mathrm{HQC}+\text { standard care/Interferon- } \beta \\
1 \mathrm{a}+\mathrm{lpv} / \mathrm{r}+\mathrm{HQC}+\text { standard care }\end{array}$ & $\begin{array}{l}\text { Enrolling by } \\
\text { invitation }\end{array}$ & IV \\
\hline
\end{tabular}


Table 2. (Continued)

\begin{tabular}{|c|c|c|c|c|}
\hline $\begin{array}{l}\text { NCT/registration } \\
\text { number }\end{array}$ & Title & Intervention/comparator & $\begin{array}{l}\text { Recruitment } \\
\text { status }\end{array}$ & Phase \\
\hline NCT04260594 & $\begin{array}{l}\text { Clinical study of arbidol } \\
\text { hydrochloride tablets in the treatment } \\
\text { of pneumonia caused by novel } \\
\text { coronavirus }\end{array}$ & $\begin{array}{l}\text { Arbidol+basic treatment/basic } \\
\text { treatment }\end{array}$ & $\begin{array}{l}\text { Not yet } \\
\text { recruiting }\end{array}$ & IV \\
\hline ChiCTR2000029621 & $\begin{array}{l}\text { Clinical study of arbidol } \\
\text { hydrochloride tablets in the treatment } \\
\text { of novel coronavirus pneumonia } \\
\text { (COVID-19) }\end{array}$ & $\begin{array}{l}\text { Arbidol+basic treatment/basic } \\
\text { treatment }\end{array}$ & Recruiting & IV \\
\hline NCT04330690 & $\begin{array}{l}\text { Treatments for COVID-19 Canadian } \\
\text { arm of the solidarity trial (CATCO) }\end{array}$ & $\begin{array}{l}\text { Remdesivir+supportive care/ } \\
\text { supportive care }\end{array}$ & Recruiting & II \\
\hline NCT04431453 & $\begin{array}{l}\text { Study to evaluate the safety, } \\
\text { tolerability, pharmacokinetics, and } \\
\text { efficacy of remdesivir (GS- } 5734^{\mathrm{TM}} \text { ) in } \\
\text { participants from birth to }<18 \text { years } \\
\text { of age with Coronavirus Disease } \\
2019 \text { (COVID-19) (CARAVAN) }\end{array}$ & Remdesivir/blank & $\begin{array}{l}\text { Not yet } \\
\text { recruiting }\end{array}$ & $\begin{array}{l}\text { II and } \\
\text { III }\end{array}$ \\
\hline NCT04321616 & $\begin{array}{l}\text { The efficacy of different anti-viral } \\
\text { drugs in COVID } 19 \text { infected patients }\end{array}$ & $\begin{array}{l}\text { Remdesivir+standard care/standard } \\
\text { care }\end{array}$ & Recruiting & $\begin{array}{l}\text { II and } \\
\text { III }\end{array}$ \\
\hline NCT04315948 & $\begin{array}{l}\text { Trial of treatments for COVID-19 in } \\
\text { hospitalized adults (discovery) }\end{array}$ & $\begin{array}{l}\text { Remdesivir+standard care/standard } \\
\text { care }\end{array}$ & Recruiting & III \\
\hline NCT04252664 & $\begin{array}{l}\text { A trial of remdesivir in adults with } \\
\text { mild and moderate COVID-19 }\end{array}$ & Remdesivir/placebo & Suspended & III \\
\hline NCT04280705 & $\begin{array}{l}\text { Adaptive COVID-19 treatment trial } \\
\text { (ACTT) }\end{array}$ & Remdesivir/placebo & Completed & III \\
\hline NCT04409262 & $\begin{array}{l}\text { A study to evaluate the efficacy and } \\
\text { safety of remdesivir plus tocilizumab } \\
\text { compared with remdesivir plus } \\
\text { placebo in hospitalized participants } \\
\text { with severe COVID-19 pneumonia } \\
\text { (REMDACTA) }\end{array}$ & $\begin{array}{l}\text { Remdesivir+tocilizumab/ } \\
\text { remdesivir+placebo }\end{array}$ & Recruiting & III \\
\hline NCT04501952 & $\begin{array}{l}\text { Study to evaluate the efficacy and } \\
\left.\text { safety of remdesivir (GS- } 5734^{\mathrm{TM}}\right) \\
\text { treatment of coronavirus disease } 2019 \\
\text { (COVID-19) in an outpatient setting }\end{array}$ & Remdesivir/placebo & $\begin{array}{l}\text { Not yet } \\
\text { recruiting }\end{array}$ & III \\
\hline NCT04345419 & $\begin{array}{l}\text { Remdesivir versus chloroquine in } \\
\text { COVID-19 }\end{array}$ & Remdesivir/chloroquine or HQC & Recruiting & III \\
\hline NCT04501978 & $\begin{array}{l}\text { Therapeutics for inpatients with } \\
\text { COVID-19 (TICO) }\end{array}$ & Remdesivir/placebo & Recruiting & III \\
\hline NCT04292899 & $\begin{array}{l}\text { Study to evaluate the safety and } \\
\text { antiviral activity of remdesivir } \\
\text { (GS-5734TM) in participants } \\
\text { with severe coronavirus disease } \\
\text { (COVID-19) }\end{array}$ & Remdesivir/standard care & completed & III \\
\hline NCT04350671 & $\begin{array}{l}\text { Interferon beta 1a in hospitalized } \\
\text { COVID-19 patients (IB1alC) }\end{array}$ & $\begin{array}{l}\text { Interferon- } \beta \\
\text { 1a+lopinavir-ritonavir+single dose } \\
\text { of HQC/lopinavir-ritonavir+single } \\
\text { dose of HQC }\end{array}$ & $\begin{array}{l}\text { Enrolling by } \\
\text { invitation }\end{array}$ & IV \\
\hline
\end{tabular}


Table 2. (Continued)

\begin{tabular}{|c|c|c|c|c|}
\hline $\begin{array}{l}\text { NCT/registration } \\
\text { number }\end{array}$ & Title & Intervention/comparator & $\begin{array}{l}\text { Recruitment } \\
\text { status }\end{array}$ & Phase \\
\hline NCT04343768 & $\begin{array}{l}\text { An investigation into beneficial } \\
\text { effects of interferon beta } 1 \mathrm{a} \text {, } \\
\text { compared to interferon beta } 1 \mathrm{~b} \text { and } \\
\text { the base therapeutic regiment in } \\
\text { moderate to severe COVID-19 a } \\
\text { randomized clinical trial (DIC) }\end{array}$ & $\begin{array}{l}\text { HQC+lopinavir-ritonavir+interferon } \\
-\beta \text { la or } \\
\text { HQC+lopinavir-ritonavir+interferon } \\
-\beta \text { 1b/lopinavir-ritonavir+HQC }\end{array}$ & Completed & IV \\
\hline NCT04254874 & $\begin{array}{l}\text { A prospective/retrospective, } \\
\text { randomized controlled clinical study } \\
\text { of interferon atomization in the } \\
2019-n C o V \text { pneumonia }\end{array}$ & $\begin{array}{l}\text { Interferon+abidol hydrochloride/ } \\
\text { abidol hydrochloride }\end{array}$ & Recruiting & IV \\
\hline NCT02735707 & $\begin{array}{l}\text { Randomized, embedded, } \\
\text { multifactorial adaptive platform trial } \\
\text { for community- acquired pneumonia } \\
\text { (REMAP-CAP) }\end{array}$ & Interferon- $\beta 1 \mathrm{a} / \mathrm{blank}$ & Recruiting & IV \\
\hline ChiCTR2000030480 & $\begin{array}{l}\text { Randomized, open, blank controlled } \\
\text { trial for the efficacy and safety of } \\
\text { recombinant human interferon alpha } \\
\text { lbeta in the treatment of Wuhan } \\
\text { patients with novel coronavirus } \\
\text { pneumonia (COVID-19) }\end{array}$ & $\begin{array}{l}\text { Standard treatment }+ \text { cerrokin } \\
\text { (recombinant human interferon } \\
\text { alpha 1beta)/standard treatment }\end{array}$ & Recruiting & IV \\
\hline ChiCTR2000030013 & $\begin{array}{l}\text { A prospective clinical study for } \\
\text { recombinant human interferon alpha } \\
1 \mathrm{~b} \text { spray in the prevention of novel } \\
\text { coronavirus (COVID-19) infection in } \\
\text { highly exposed medical staffs. }\end{array}$ & $\begin{array}{l}\text { Recombinant human interferon } \alpha 1 b \\
\text { spray/blank }\end{array}$ & $\begin{array}{l}\text { Not yet } \\
\text { recruiting }\end{array}$ & IV \\
\hline ChiCTR2000029989 & $\begin{array}{l}\text { A randomized controlled trial for } \\
\text { therapeutic efficacy of recombinant } \\
\text { human interferon alpha } 1 \mathrm{~b} \text { eye drops } \\
\text { in the treatment of elderly with novel } \\
\text { coronavirus pneumonia (COVID-19) }\end{array}$ & $\begin{array}{l}\text { Recombinant human interferon } \alpha 1 b \\
\text { eye drops/placebo drop }\end{array}$ & $\begin{array}{l}\text { Not yet } \\
\text { recruiting }\end{array}$ & IV \\
\hline NCT04255017 & $\begin{array}{l}\text { A prospective/retrospective, } \\
\text { randomized controlled clinical study } \\
\text { of antiviral therapy in the } 2019-\mathrm{nCoV} \\
\text { pneumonia }\end{array}$ & $\begin{array}{l}\text { Oseltamivir+symptomatic } \\
\text { supportive treatment/symptomatic } \\
\text { supportive treatment }\end{array}$ & Recruiting & IV \\
\hline NCT02735707 & $\begin{array}{l}\text { Randomized, embedded, } \\
\text { multifactorial adaptive platform trial } \\
\text { for community- acquired pneumonia } \\
\text { (REMAP-CAP) }\end{array}$ & Oseltamivir/blank & Recruiting & IV \\
\hline NCT04355026 & $\begin{array}{l}\text { Use of bromhexine and } \\
\text { hydroxychloroquine for treatment of } \\
\text { COVID-19 pneumonia }\end{array}$ & HQC+bromhexine/HQC & Recruiting & IV \\
\hline NCT04405999 & $\begin{array}{l}\text { Prevention of infection and } \\
\text { incidence of COVID-19 in medical } \\
\text { personnel assisting patients with new } \\
\text { Coronavirus Disease }\end{array}$ & Bromhexine hydrochloride/blank & Recruiting & IV \\
\hline
\end{tabular}

significantly longer in the LPV/r group compared to the arbidol group $(p<0.01)$, which suggested that arbidol monotherapy has better clinical efficacy than
$\mathrm{LPV} / \mathrm{r}$ [64]. In addition, in a retrospective cohort study, the combination of arbidol and LPV/r was proved to be more efficient than monotherapy with 
arbidol $(p<0.05)$ [65]. The main adverse reactions of arbidol include slow heart rate, nausea, diarrhea, and it must be avoided in combination with metoprolol, propranolol (Propranol), and other beta receptor antagonists, and when the heart rate is $<60$ beats $/ \mathrm{min}$, it is recommended to stop the application [66].

\subsubsection{Antivirals: LPV/r and darunavir-cobicistat}

The combination of LPV/r has been approved by the FDA for the treatment of HIV. Against SARS$\mathrm{CoV}-1$, lopinavir at $4 \mu \mathrm{g} / \mathrm{ml}$ caused inhibition of its growth after $48 \mathrm{~h}$ of incubation [67]. In vitro studies showed that lopinavir has an EC50 of 17.1 $\mu \mathrm{M}$ against SARS-CoV-1 [68]. Worth mentioning that the addition of LPV/r to IFN $\beta$ against MERS$\mathrm{CoV}$ did not significantly increase the efficacy of IFN $\beta$ in vitro or in vivo, but they exacerbated the lung disease in vivo [60]. Another study showed opposite results [69]. Based on a recent study, lopinavir, but not ritonavir, had an EC50 of $26.63 \mu \mathrm{M}$ against SARS-CoV-2 [70].

In a study in China involving 40 patients, all patients were given LPV/r (200 mg/50 mg/tablet, 2 tablets bid) and traditional Chinese medicine. After 6 - 30 days of admission, new coronavirus nucleic acid turned negative in all patients. In this report, the authors also pointed out that the incidence of adverse reactions of LPV/r was high for total adverse reactions $(72.5 \%)$, including elevated triglyceride $(50 \%)$, adverse reactions of the digestive system $(42.5 \%)$, and termination of the therapy due to intolerable reactions $(7.5 \%)$, which were mostly related to the digestive system, such as nausea and diarrhea [71]. A critically ill case in Japan was administered LPV/r through a nasogastric tube, the patient was moved out of ICU on day 15 and was discharged on day 24 [72]. However, several other reports argued that LPV/r showed no benefit in clinical improvement [73] or viral clearance [74] compared with standard of care (i.e., necessary supplemental oxygen, non-invasive and invasive ventilation, antibiotic agents, vasopressor support, renal-replacement therapy, and extracorporeal membrane oxygenation [ECMO]). A Chinese study found that among 119 patients who received LPV/r-based antiretroviral treatments regimen, no COVID-19 case occurred. Although the study results failed to indicate that the LPV/r antiretroviral treatment regimen is significantly related to predict reducing COVID-19, it still suggests that LPV/r may act as prophylaxis [75].

The mechanism of action of darunavir and cobicistat is basically the same as LPV/r. Both are protease inhibitors, and cobicistat is also a cytochrome P450 and GP inhibitor [76]. As demonstrated in an in vitro study, darunavir had antiviral activity against SARS-CoV-2 at a concentration of $300 \mu \mathrm{M}$ [63]. Clinical studies have shown that the gastrointestinal tolerance of darunavir is relatively higher than that of $\mathrm{LPV} / \mathrm{r}$, so patients with serious gastrointestinal adverse effects can be treated with darunavir/cobicistat (oral, 1 tablet/day) or favipiravir (first dose $1600 \mathrm{mg}$, subsequent $600 \mathrm{mg}, 3$ times/day) $[55,66]$.

Since all above drugs are metabolized by liver cytochrome P450, extra attention should be paid to drug-drug interactions. Patients with hepatic dysfunction should be closely monitored for liver function and adverse reactions during treatment [77].

\subsubsection{Antivirals: Ribavirin}

Ribavirin is an antiviral that inhibits viral replication by inhibiting RNA-dependent RNA polymerase. It showed activity against SARS-CoV-1 in some studies but, it required high doses such as $1.2-$

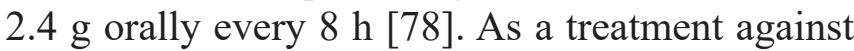
SARS-CoV-2, ribavirin had an EC50 of $109.5 \mu \mathrm{M}$ which indicated it is 100 times less potent than remdesivir [48].

\subsubsection{Antivirals: Favipiravir}

Favipiravir is a prodrug which generates an active moiety called favipiravir ribofuranosyl-5'triphosphate which inhibits the RNA-dependent RNA polymerase enzyme in influenza and Ebola viruses. One in vitro study showed that EC50 of favipiravir against SARS-COV-2 is $61.88 \mu \mathrm{M}$ [48]. On the other hand, Choy Kt et al. depicted that favipiravir failed to demonstrate any antiviral activity against SARS-CoV-2 in vitro at concentrations below $100 \mu \mathrm{M} / \mathrm{L}$ [70].

\subsubsection{Antiviral immunotherapy IFN}

Type 1 IFN-1 are a group of cytokines secreted by various cells, especially plasmacytoid dendritic cells. They are recognized by the type I IFN heterodimeric receptor complex comprising 
IFN- $\alpha$ receptor 1 (IFNAR1) and IFNAR2 subunits on the plasma membrane in most of cells. They can eventually decrease membrane fluidity and prevent membrane fusion by upregulating the expression of the $\mathrm{CH} 25 \mathrm{H}$ gene, the protein product of which is an enzyme that can change cholesterol into 25-hydroxycholesterol (25HC). Subsequently, $25 \mathrm{HC}$ mediates the infectious cycle at the virushost membrane fusion step [79]. In SARS-CoV-1, open reading frame (ORF) $3 \mathrm{~b}$ protein prohibits the phosphorylation of IRF3, which plays a key role in the activation of IFN expression. Furthermore, the ORF6 protein of SARS-CoV inhibits the import of transcriptional factors in the nucleus by disrupting karyopherin transport, which eventually leads to IFN response. The ORF3b and ORF6 proteins are truncated in SARS-CoV-2 that might explain its higher sensitivity to IFN $\alpha$ as compared to MERS$\mathrm{CoV}$ and SARS-CoV-1 [80]. Both IFN $\alpha$ and IFN $\beta$ stimulate innate antiviral responses. They showed activity against MERS-CoV with EC50 of $175 \mathrm{IU} / \mathrm{mL}$ [81]. In a clinical research, 77 adults with confirmed COVID-19 were divided into three treatment groups: Nebulized IFN- $\alpha 2 b$ group $(n=7)$, arbidol group $(n=24)$, and IFN- $\alpha 2$ b plus arbidol group $(n=46)$. The average days for viral clearance were 21.1, 27.9, and 20.3 for IFN- $\alpha 2 b$ group, arbidol group, and IFN- $\alpha 2 b$ plus arbidol group, respectively, indicated that regardless of the use of arbidol, IFN- $\alpha 2 b$ can shorten the process of viral clearance. The result suggests that IFN$\alpha 2 b$ need to be further explored as a treatment in COVID-19 patients [82]. Related clinical trials are shown in Table 2.

\subsubsection{Other antiviral agents}

Penciclovir was tested against SARS-CoV-2 in vitro and had an EC50 of $95.96 \mu \mathrm{M}$ and CC50 >400 $\mu \mathrm{M}$. Nafamostat was tested in the same study and had EC50 of $22.5 \mu \mathrm{M}$ and CC50 >100 $\mu \mathrm{M}$ [48].

Oseltamivir was used with other antimicrobials in patients who contracted SARS-CoV-2 in China before its etiology was identified. It is not recommended to use oseltamivir in COVID-19 as SARS-CoV-2 lacks the neuraminidase enzyme (the target of oseltamivir) [84]. Oseltamivir failed to inhibit SARS-CoV-1 even at a concentration of 10,000 $\mu \mathrm{M}$ [81]. However, a case in Thailand showed that the combination of oseltamivir and
$\mathrm{LPV} / \mathrm{r}$ was efficient in improving the conditions and the patient was virologically negative after $48 \mathrm{~h}$ of treatment. Furthermore, two patients in Australia recovered successfully from COVID-19 after being treated with oseltamivir [85].

\subsection{Immunomodulatory agents}

SARS-CoV-2 infection activates $\mathrm{CD} 14^{+} \mathrm{CD} 16^{+}$ monocyteswithhighexpressionofIL-6thatcontribute to COVID-19 progression. These data suggest that IL-6 inhibitors, such as tocilizumab, may help control COVID-19-induced hyperinflammatory condition, a factor for high mortality in COVID-19 patients [86]. A report examined the elevation of IL-6 among severe COVID-19 patients. The result showed the mean level of serum IL-6 among severe patients was $56.8 \mathrm{pg} / \mathrm{mL}(41.4-72.3 \mathrm{pg} / \mathrm{mL})$, which was significantly higher than $17.3 \mathrm{pg} / \mathrm{mL}$ $(13.5-21.1 \mathrm{pg} / \mathrm{mL}, p<0.001)$ recorded from non-severe patients [87]. Tocilizumab is an IL-6 receptor-specific monoclonal antibody approved by the FDA for the treatment of cytokine release syndrome [88]. However, a research involving three severe cases who received tocilizumab ( $8 \mathrm{mg} / \mathrm{kg}$, intravenous infusion for more than $1 \mathrm{~h})$ resulted in no significant effect on the level of COVID-19-related inflammatory factors in them [89]. Furthermore, some researchers argued that the utilization of tocilizumab in early stage may promote the replication of the virus as a result of the decrease in IL-6 [90]. Henceforth, the efficacy and safety of tocilizumab in the management of COVID-19 need to be further evaluated.

\subsubsection{Anti-S protein monoclonal antibodies}

The antibody CR3022 (originally developed to fight SARS-CoV-1) can bind potently to the receptor-binding domain (RBD) within the $\mathrm{S}$ protein of SARS-CoV-2 and thus, inhibit its entry to host cells [91]. However, Zheng et al. showed that $85 \%$ RBD antibody epitopes in SARS-CoV-2 are significantly altered when compared with SARS-CoV-1, which means that new antibodies are needed for SARS-CoV-2 [92].

\subsubsection{Corticosteroids}

The use of corticosteroids in the management of SARS-CoV-2 is a double-edged sword. While they reduce the inflammatory response in the lungs and 
thereby reduce the risk for acute lung injury and ARDS, they, on the other hand, delay the viral clearance and increase the risk for secondary infection [93]. A study pointed out that severe COVID-19 patients may benefit from precise lowdose corticosteroid treatment [94]. The routine use of corticosteroid is not recommended by the National Health Commission of China. The recommended dose and duration of therapy of methylprednisolone for patients with progressive deterioration of oxygenation indicator, rapid imaging progress, or excessive activation of the inflammatory response in the body is no more than $1-2 \mathrm{mg} / \mathrm{kg} /$ day for $3-5$ days. During the management, the condition and efficacy should be evaluated every 2 or 3 days. Compared with hydrocortisone and dexamethasone, methylprednisolone has long elimination half-life $(1.8-5.2 \mathrm{~h})$ and moderate effect, and it is easy to administer. Furthermore, it exerts a less inhibitory effect on the hypothalamic-pituitary-adrenal axis (HPA). It is directly metabolized by the liver CYP3A4 enzyme to an inactive metabolite; therefore, methylprednisolone is a more suitable therapeutic candidate for COVID-19 [66].

\subsubsection{Peptides and proteins-based agents}

Heptad repeat 1 and 2 (HR1 and HR2) are from the surface structures that facilitate SARS-CoV-2 entry into host cells. An in vitro study showed that HR2-derived peptides (HR2P) and EK1 (modified HR2P peptide) inhibited the fusion of SARSCoV-2 to host cells [95]. Nguyen et al. reported a cleaving system for SARS-CoV-2 RNA genome. This CRISPR/Cas13 system contained a Cas13d protein in addition to RNA containing sequences designed specifically to target SARS-CoV-2 RNA genome. The system can be delivered to lung cells by adeno-associated virus (AAV) [96].

One recent study demonstrated that human recombinant soluble ACE2 (hrsACE2) protein inhibits the attachment of SARS-CoV-2 to Vero-E6 cells in a dose-dependent manner [97]. The study also showed that hrsACE2 reduces the infection of human capillary organoids and human kidney organoids by SARS-CoV-2. Lei et al. designed two fusion proteins consisting of the extracellular domain of the human ACE2 attached to Fc domain of human IgG1. Those proteins were able to bind to the RBD on SARS-CoV-2 with high affinity. The in vitro IC50 of the designed proteins against SARS-CoV-2 was 0.03 and $0.1 \mu \mathrm{g} / \mathrm{ml}$ [98].

\subsubsection{Vitamin $C$}

Vitamin C, also known as ascorbic acid, has a strong reducing property and can, therefore, be used as antioxidants. It can help to improve the immune system and prevent the oxidation vital biomolecules including proteins, lipids, and DNA. During infection, the level of vitamin decreases and the body's demand for Vitamin C will increase accordingly [99]. In the management of severe and late stages of COVID-19, the application of Vitamin C could efficiently decrease cytokine storm [100]. Furthermore, it was proved that high-dose Vitamin $\mathrm{C}$ infusion can reduce the mortality of patients with ARDS [101]. In a study, intravenous Vitamin C was used as adjuvant therapy for virus-induced ARDS. A 20-year-old woman was infected by enterovirus/ rhinovirus and developed dyspnea and hypoxemia, which rapidly developed into acute lung injury, eventually leading to ARDS. ECMO was used for the patient with a large dose of intravenous vitamin C (200 mg/kg every $24 \mathrm{~h}$ ). After treatment, the patient's lung gas exchange was significantly improved. After 12 days, the patient was discharged from the hospital without long-term ARDS sequelae [102]. As ARDS considered being the main complication of COVID-19, Vitamin C can be regarded as a potent adjuvant drug. In a retrospective analysis of COVID-19 in 71 cases, all patients were given Vitamin C injection (4 g/time/day, intravenous drip), and the outcome suggested that the application of high-dose Vitamin $\mathrm{C}$ may play a key role in the protection of lung tissue [103]. Relevant clinical trials are shown in Table 3.

\subsubsection{Antibiotic treatment and other pharmacological therapies}

It is reported that the overuse of antibiotic drugs with the absence of infection can induce the secretion of pro-inflammatory cytokines (IL$1 b$, IL-6, and TNF- a) and eventually lead to sepsis and especially septic shock during the treatment of COVID-19 [104]. Therefore, regular or inappropriate use of antibiotic drugs is not recommended during the treatment, especially in combination with broad-spectrum antibiotic drugs. 
Table 3. Ongoing clinical trials with anti-inflammatory drugs for COVID-19 as of October 26, 2020 $[71,83]$

\begin{tabular}{|c|c|c|c|c|}
\hline $\begin{array}{l}\text { NCT/registration } \\
\text { number }\end{array}$ & Title & $\begin{array}{l}\text { Intervention/ } \\
\text { comparator }\end{array}$ & $\begin{array}{l}\text { Recruitment } \\
\text { status }\end{array}$ & Phase \\
\hline NCT04363216 & $\begin{array}{l}\text { Pharmacologic ascorbic acid as an activator of } \\
\text { lymphocyte signaling for COVID-19 treatment }\end{array}$ & $\begin{array}{l}\text { Vitamin c/routine } \\
\text { care }\end{array}$ & $\begin{array}{l}\text { Not yet } \\
\text { recruiting }\end{array}$ & II \\
\hline NCT04344184 & $\begin{array}{l}\text { Early infusion of Vitamin } C \text { for the treatment } \\
\text { of novel COVID-19 acute lung injury } \\
\text { (EVICT-CORONA-ALI) }\end{array}$ & Vitamin C/placebo & $\begin{array}{l}\text { Not yet } \\
\text { recruiting }\end{array}$ & II \\
\hline NCT04264533 & $\begin{array}{l}\text { Vitamin C infusion for the treatment of severe } \\
\text { 2019-nCoV infected pneumonia }\end{array}$ & Vitamin C/placebo & Recruiting & II \\
\hline NCT04401150 & $\begin{array}{l}\text { Lessening organ dysfunction with Vitamin C - } \\
\text { COVID-19 (LOVIT-COVID) }\end{array}$ & Vitamin C/placebo & Recruiting & III \\
\hline NCT04354428 & $\begin{array}{l}\text { Treatment for COVID-19 in high-risk adult } \\
\text { outpatients }\end{array}$ & Vitamin c/placebo & Recruiting & III \\
\hline NCT04468139 & $\begin{array}{l}\text { The study of quadruple therapy zinc, quercetin, } \\
\text { bromelain and Vitamin C on the clinical outcomes } \\
\text { of patients infected with COVID-19 }\end{array}$ & Vitamin c/blank & Recruiting & IV \\
\hline NCT04263402 & $\begin{array}{l}\text { The efficacy of different hormone doses in } \\
2019 \text {-nCoV severe pneumonia }\end{array}$ & $\begin{array}{l}\text { Methylprednisolone/ } \\
\text { blank }\end{array}$ & Recruiting & IV \\
\hline NCT02735707 & $\begin{array}{l}\text { Randomized, embedded, multifactorial adaptive } \\
\text { platform trial for community-acquired pneumonia } \\
\text { (REMAP-CAP) }\end{array}$ & Tocilizumab/blank & Recruiting & IV \\
\hline NCT04377750 & $\begin{array}{l}\text { The use of tocilizumab in the management of } \\
\text { patients who have severe COVID- } 19 \text { with suspected } \\
\text { pulmonary hyperinflammation }\end{array}$ & Tocilizumab/placebo & Recruiting & IV \\
\hline ChiCTR2000030894 & $\begin{array}{l}\text { Favipiravir combined with tocilizumab in the } \\
\text { treatment of novel coronavirus pneumonia } \\
\text { (COVID-19) - a multicenter, randomized, controlled } \\
\text { trial }\end{array}$ & $\begin{array}{l}\text { Favipiravir+ } \\
\text { tocilizumab/ } \\
\text { favipiravir or } \\
\text { tocilizumab }\end{array}$ & Recruiting & IV \\
\hline ChiCTR2000030580 & $\begin{array}{l}\text { Efficacy and safety of tocilizumab combined with } \\
\text { adamumab (QLETLI) in severe and critical patients } \\
\text { with novel coronavirus pneumonia (COVID-19) }\end{array}$ & $\begin{array}{l}\text { Tocilizumab }+ \\
\text { adamumab }+ \text { standard } \\
\text { care/standard care }\end{array}$ & Recruiting & IV \\
\hline
\end{tabular}

In cases where there is a basic disease or evidence that there is a secondary bacterial infection or a severe patient, the symptomatic use of related antibacterial drugs may be considered [55].

Nitazoxanide in in vitro studies against SARSCoV-2 had an EC50 of $2.12 \mu \mathrm{M}$ and CC50> $35.53 \mu \mathrm{M}$ at $48 \mathrm{~h}$. The active metabolite of nitazoxanide, tizoxanide, was shown to be more potent with an EC50 of $0.92 \mu \mathrm{M}$ in the same study [48]. Nitazoxanide demonstrated potent activity against MERS-CoV [47]. The mechanism of action of nitazoxanide is believed to be pathways involved in viral replication in addition to those mechanisms that the virus targets host to avoid host defense. This could be the mechanism of activity of nitazoxanide against a range of viruses including influenza, respiratory syncytial virus, rotavirus, norovirus, and coronaviruses [47].

Ivermectin is an FDA-approved agent against parasitic infections. Moreover, it was proved that it can inhibit HIV-1 replication and limit inflammation caused by some RNA viruses such as influenza, dengue, and west Nile viruses. In an in vitro study against SARS-CoV-2, ivermectin reduced the viral RNA by about 5,000 fold after 48 $\mathrm{h}$ of its addition to Vero-hSLAM cells infected with SARS-CoV-2 [105].

One study suggested that metronidazole may help to control the inflammatory conditions associated with SARS-CoV-2 by reducing the 
levels of IL-8, IL-6, IL-1 $\beta$, TNF $\alpha$, IL-12, and IFN $\gamma$ in addition to reducing the number of circulating lymphocytes and neutrophil-generated reactive oxygen species [106]. The host cellular serine protease TMPRSS2 interacts with the $\mathrm{S}$ protein to facilitate viral entry into host cells. Camostat mesylate in one study inhibited TMPRSS2 and reduced the entry of SARS-CoV-2 into host lung cells [107]. Bromhexine is a transmembrane protease serine inhibitor that has been used as a mucolytic cough suppressant [108]. In China, it is under investigation as a mucolytic drug in suspected and mild patients who have chest congestion and cough (NCT04273763) [109].

\subsubsection{Plasma exchange}

Plasma exchange is a type of plasmapheresis. It concerns with removing patients' plasma and exchanging it with fresh plasma, albumin solution, and balanced fluids at the same speed. In this way, the reduction of pathological damage and decrease of pathogenic substances can be achieved. This is also known as extracorporeal blood purification which is widely used in patients with immune diseases [110]. In the first case, the patient showed persisted leukopenia and elevated inflammatory markers, including CRP $(105.5 \mathrm{mg} / \mathrm{L}$, reference $0-3 \mathrm{mg} / \mathrm{L})$, and IL-6 (54.57 $\mathrm{pg} / \mathrm{mL}$, reference $0-7 \mathrm{pg} / \mathrm{mL}$ ). After receiving three sessions of plasma exchange, the parameters persistently increased. Antiphospholipid antibodies including anti- $\beta 2$ glycoprotein-I (258.1CU, reference $0-20 \mathrm{CU})$ and anticardiolipin (43.2CU, reference $0-20 \mathrm{CU}$ ) were positive on day 26. The presence of these antibodies could indicate an early anticoagulation of patients with COVID-19 [111]. Therefore, a plasma exchange was given on day 29 , with two following sessions of plasma exchange. A rapid reduction of the titers of antiphospholipid antibodies and inflammatory marker were observed [112]. In another case with persistent diarrhea, four sessions of plasma exchange followed by intravenous Ig (IVIG) were performed, and the patient's condition stabilized with no more diarrhea episodes [113]. In addition, a study involving three patients pointed out that after plasma exchange, the level of inflammatory factors significantly decreased for CRP (from $84.81 \mathrm{mg} / \mathrm{mL}$ to $9.2 \mathrm{mg} / \mathrm{mL}$ ) and IL-6 (from $12.14 \mathrm{pg} / \mathrm{mL}$ to $4.33 \mathrm{pg} / \mathrm{mL}$ ), which confirmed the effectiveness of plasma exchange therapy in COVID-19 patients [89].

\subsubsection{Convalescent plasma or hyperimmune Ig therapy}

Convalescent plasma or hyperimmune Ig therapy is defined as the plasma collected from individuals after recovering from the infection and antibody development. With the infusion of convalescent plasma, passive antibodies are transfused into the patients and provide susceptible populations with immediate immunity [114]. Convalescent plasma therapy has been used in the management of many virus infections including SARS, MERS, and Ebola virus [115]. A clinical study carried out by Nanjing University analyzed the efficacy of convalescent plasma among six patients in which all patients were given the transfusion of ABO-compatible convalescent plasma. The result showed that the GGOs of five patients resolved and the density of consolidation reduced after receiving transfusion of convalescent plasma. Among two patients who presented with positive SAR-CoV-2 in throat swab, convalescent plasma therapy could eliminate the virus. In addition, the titers of anti-SARS-CoV-2 antibody in two patients increased immediately. The result suggested that convalescent plasma therapy is clinically beneficial [116]. In addition, two severe cases with ARDS from South Korea showed positive results after receiving convalescent plasma therapy [117]. However, a study showed that all patients turned to virologically negative state by the $3^{\text {rd }}$ day after using convalescent plasma therapy but five of them died eventually. Thus, the researchers argued that the application of convalescent plasma could only improve the results of virological tests but exert no positive effect on reducing the mortality in critically end-stage COVID-19 patients. Furthermore, the researchers pointed out that the treatment should be utilized earlier [118].

\subsubsection{Adjuvant therapy}

Maintaining a good nutritional status is important for immune system function [119], so it is recommended by Chinese experts to retain the nasogastric tube for gastric nutrition in severe patients. If gastric nutrition is not suitable, a pyloric feeding route, such as nasointestinal tube, should be adopted [55]. In addition, it is recommended by 
the National Health Commission of China to use micro-ecological regulators to maintain intestinal micro-ecological balance and prevent secondary bacterial infections [66].

\subsubsection{Vaccine}

At present, there is still no new drug for COVID-19, and the vaccine is not only cost-effective but also can effectively control disease infection from the source, so the development of vaccines for treatment and prevention is of great significance. At present, $\mathrm{S}$ protein is the most promising antigen for the SARS-Cov-2 vaccine not only because it is on the surface of the virus for easier recognition but also it mediates the interaction between the virus and host cell receptor ACE2. Moreover, previous researches on SARS-CoV and MERS-CoV indicated that $\mathrm{S}$ protein was a favorable antigen for the development of vaccines [120]. Vaccines that targeted other antigens are also under studies, including whole-cell killed and live-attenuated vaccines, subunit vaccines, mRNA vaccines, DNA vaccines, and live vector vaccines $[120,121]$.

In a dose-escalation, single-center, open-label, non-randomized, Phase 1 trial, and an adenovirus type-5 (Ad5) vectored COVID-19 vaccine were investigated. This vaccine used the $\mathrm{S}$ glycoprotein of a SARS-Cov-2 strain. In this trial, 108 healthy adults were divided into three dose groups who received intramuscular injections of low-dose $\left(5 \times 10^{10}\right)$, middle-dose $\left(1 \times 10^{11}\right)$, and high-dose $\left(1.5 \times 10^{11}\right)$ viral particles. Within the first 7 days after the injection, the percentage of participants who reported at least one adverse reaction was $83 \%, 83 \%$, and $75 \%$ in the low-, middle-, and high-dose groups, respectively. Among all dose groups, the most common systemic adverse events were fever (46\%), fatigue (44\%), headache (39\%), and muscle pain (17\%), of which most were mild or moderate. On day 14, ELISA antibodies and neutralizing antibodies showed a significant increase and specific T-cell responses were noted. On day 28, ELISA antibodies and neutralizing antibodies reached the peak. The result indicated that the Ad5 vectored COVID-19 vaccine need to be further investigated for the control of COVID-19 [122].

In another randomized, double-blind, placebocontrolled, Phase II trial (NCT04341389), the safety and immunogenicity of Ad5 vectored COVID-19 vaccine were investigated. Healthy adults $(n=603)$ were divided randomly into two vaccine group (high-dose: $1 \times 10^{11}$ viral particles, $n=253$; low-dose: $5 \times 10^{10}$ viral particles, $n=129)$ or placebo group $(n=126)$. On day 28 after a single intramuscular injection in the arm, both doses of vaccine could significantly induce neutralizing antibody. The geometric mean titers of the antibody were 19.5 (95\% CI $16.8-22.7)$ and 18.3 (14.4 - 23.3) among the high-dose and low-dose group, respectively. However, 24 participants in high-dose groups and one in lowdose group reported severe adverse effects, none of them were serious reactions. These results indicated the Ad5 vectored COVID-19 vaccine at a dose of $5 \times 10^{10}$ viral particles is safe and immunogenic [3]. In a single-blind, randomized controlled, Phase I/II trial (NCT04324606), the safety and immunogenicity of a chimpanzee adenovirus-vectored vaccine (ChAdOx $1 \mathrm{nCoV}-19$ ) expressing the SARS-CoV-2 spike protein was studied. Healthy adults were divided randomly into vaccine group to receive ChAdOx1 nCoV-19 at a dose of $5 \times 10^{10}$ viral particles or control group to receive a meningococcal conjugate vaccine (MenACWY). Ten participants were involved in a non-randomized, unblinded ChAdOx 1 nCoV-19 prime-boost study and received a booster vaccine 28 days after the first administration. The responses of anti-spike $\operatorname{IgG}$ increased by day 28 (157 ELISA units, 96-317) and boosted after a second dose (639 ELISA units, $360-792, n=10$ ). Neutralizing antibody was detected after a single dose of vaccine administration. No serious adverse events were reported [123]. A group of Russian researchers developed a heterologous COVID-19 vaccine consisting of a recombinant adenovirus type $26(\mathrm{rAd} 26)$ vector and a recombinant adenovirus type 5 (rAd5) vector carrying the gene of SARS-CoV-2 spike glycoprotein, rAd26-S and rAd5-S, respectively. Importantly, the vaccine was produced in two formulations, frozen, and lyophilized. Two open, non-randomized Phase I/ II studies were carried out to test the safety and immunogenicity of this vaccine. In Phase I study, the safety of the two components was assessed by administering a single intramuscular injection of either rAd26-S or rAd5-S. The result indicated that 
both components were safe as no serious adverse reactions were observed. In the Phase II study, participants were assigned to receive $\mathrm{rAd} 26-\mathrm{S}$ on day 0 and rAd5-S on day 21 intramuscularly. On day 42 , both formulations of this heterologous vaccine could significantly increase the amount of anti-spike IgG and neutralizing antibody [124]. There are several other ongoing vaccine-related trials that are summarized in Table 4 (data not published yet).

Table 4. Ongoing clinical trials with vaccines for COVID-19 as of October 26, 2020 [83]

\begin{tabular}{|c|c|c|c|c|c|}
\hline $\begin{array}{l}\mathrm{NCT} / \\
\text { registration } \\
\text { number }\end{array}$ & Title & Intervention & $\begin{array}{l}\text { Recruitment } \\
\text { status }\end{array}$ & Phase & Country \\
\hline NCT04405908 & $\begin{array}{l}\text { SCB-2019 as COVID-19 } \\
\text { vaccine }\end{array}$ & $\begin{array}{l}\text { SCB-2019/SCB-2019 with } \\
\text { AS03 adjuvant/SCB-2019 with } \\
\text { CpG } 1018 \text { adjuvant plus Alum } \\
\text { adjuvant }\end{array}$ & Recruiting & I & Australia \\
\hline NCT04453852 & $\begin{array}{l}\text { Monovalent recombinant } \\
\text { COVID-19 vaccine } \\
(\text { COVAX19) }\end{array}$ & $\begin{array}{l}\text { COVID-19 recombinant } \\
\text { spike protein with Advax-SM } \\
\text { adjuvant (COVAX-19 vaccine) }\end{array}$ & Recruiting & I & Australia \\
\hline NCT04368988 & $\begin{array}{l}\text { Evaluation of the safety } \\
\text { and immunogenicity of a } \\
\text { SARS-CoV-2 rS (COVID-19) } \\
\text { nanoparticle vaccine with/ } \\
\text { without Matrix-M adjuvant }\end{array}$ & $\begin{array}{l}\text { SARS-CoV-2 rS/SARS-CoV-2 } \\
\text { rS with Matrix-M }\end{array}$ & $\begin{array}{l}\text { Active, not } \\
\text { recruiting }\end{array}$ & I & Australia \\
\hline NCT04495933 & $\begin{array}{l}\text { A study on the safety, } \\
\text { tolerability and immune } \\
\text { response of SARS-CoV-2 } \\
\text { Sclamp (COVID-19) vaccine } \\
\text { in healthy adults }\end{array}$ & $\begin{array}{l}\text { MF59 adjuvanted } \\
\text { SARS-CoV-2 Sclamp vaccine }\end{array}$ & Recruiting & I & Australia \\
\hline NCT04334980 & $\begin{array}{l}\text { Evaluating the safety, } \\
\text { tolerability and } \\
\text { immunogenicity of } \\
\text { bacTRL-Spike vaccine for } \\
\text { prevention of COVID-19 }\end{array}$ & bacTRL-Spike & $\begin{array}{l}\text { Not yet } \\
\text { recruiting }\end{array}$ & I & Australia \\
\hline NCT04369794 & $\begin{array}{l}\text { COVID- } 19 \text { BCG as } \\
\text { therapeutic vaccine, } \\
\text { transmission limitation, and } \\
\text { immunoglobulin enhancement } \\
\text { (BATTLE) }\end{array}$ & $\begin{array}{l}\text { Calmette Guerin bacillus } \\
\text { vaccine }\end{array}$ & Recruiting & IV & Brazil \\
\hline NCT04568811 & $\begin{array}{l}\text { The phase I clinical trial } \\
\text { of booster vaccination of } \\
\text { Adenovirus Type- } 5 \text { Vectored } \\
\text { COVID-19 Vaccine }\end{array}$ & $\begin{array}{l}\text { Adenovirus type- } 5 \text { vectored } \\
\text { COVID-19 vaccine }\end{array}$ & $\begin{array}{l}\text { Active, not } \\
\text { recruiting }\end{array}$ & I & China \\
\hline NCT04551547 & $\begin{array}{l}\text { Safety and immunogenicity } \\
\text { study of inactivated vaccine } \\
\text { for prevention of COVID-19 }\end{array}$ & $\begin{array}{l}\text { Inactivated SARS-CoV-2 } \\
\text { vaccine }\end{array}$ & $\begin{array}{l}\text { Not yet } \\
\text { recruiting }\end{array}$ & $\begin{array}{l}\text { I and } \\
\text { II }\end{array}$ & China \\
\hline NCT04530656 & $\begin{array}{l}\text { Phase I trial of a recombinant } \\
\text { SARS-CoV-2 vaccine (Sf9 } \\
\text { Cell) }\end{array}$ & $\begin{array}{l}\text { Recombinant SARS-CoV-2 } \\
\text { vaccine (Sf9 Cell) }\end{array}$ & $\begin{array}{l}\text { Not yet } \\
\text { recruiting }\end{array}$ & I & China \\
\hline NCT04552366 & $\begin{array}{l}\text { A clinical trial of a } \\
\text { recombinant adenovirus } 5 \\
\text { vectored covid-19 vaccine } \\
\text { (Ad5-nCoV) With two doses } \\
\text { in healthy adults }\end{array}$ & Ad5-nCoV & Recruiting & I & China \\
\hline
\end{tabular}


Table 4. (Continued)

\begin{tabular}{|c|c|c|c|c|c|}
\hline $\begin{array}{l}\mathrm{NCT} / \\
\text { registration } \\
\text { number }\end{array}$ & Title & Intervention & $\begin{array}{l}\text { Recruitment } \\
\text { status }\end{array}$ & Phase & Country \\
\hline NCT04566770 & $\begin{array}{l}\text { Phase IIb clinical trial } \\
\text { of a COVID-19 vaccine } \\
\text { named recombinant novel } \\
\text { coronavirus vaccine } \\
\text { (adenovirus type } 5 \text { vector) }\end{array}$ & $\begin{array}{l}\text { Recombinant novel } \\
\text { coronavirus vaccine } \\
\text { (adenovirus type } 5 \text { vector) }\end{array}$ & Recruiting & II & China \\
\hline NCT04550351 & $\begin{array}{l}\text { Recombinant new coronavirus } \\
\text { vaccine (CHO Cells) to } \\
\text { prevent SARS-CoV-2 phase I } \\
\text { clinical trial (ria years old) }\end{array}$ & $\begin{array}{l}\text { Recombinant new coronavirus } \\
\text { vaccine (CHO cell) }\end{array}$ & Recruiting & $\begin{array}{l}\text { I and } \\
\text { II }\end{array}$ & China \\
\hline NCT04523571 & $\begin{array}{l}\text { Safety and immunogenicity } \\
\text { of sars-cov-2 mrna vaccine } \\
\text { (BNT162b1) in } 36 \text { almett } \\
\text { healthy subjects }\end{array}$ & $\begin{array}{l}\text { SARS-CoV-2 mRNA vaccine } \\
\text { BNT162b1 }\end{array}$ & Recruiting & I & China \\
\hline NCT04383574 & $\begin{array}{l}\text { Safety and immunogenicity } \\
\text { study of inactivated } \\
\text { vaccine for prevention of } \\
\text { SARS-CoV-2 infection } \\
\text { (COVID-19) }\end{array}$ & $\begin{array}{l}\text { Inactivated SARS-CoV-2 } \\
\text { vaccine }\end{array}$ & $\begin{array}{l}\text { Active, not } \\
\text { recruiting }\end{array}$ & $\begin{array}{l}\text { I and } \\
\text { II }\end{array}$ & China \\
\hline NCT04470609 & $\begin{array}{l}\text { Safety and immunogenicity } \\
\text { study of an inactivated } \\
\text { SARS-CoV-2 vaccine for } \\
\text { preventing against COVID-19 } \\
\text { in people aged } \geq 60 \text { years }\end{array}$ & $\begin{array}{l}\text { Inactivated SARS-CoV-2 } \\
\text { vaccine }\end{array}$ & $\begin{array}{l}\text { Enrolling by } \\
\text { invitation }\end{array}$ & $\begin{array}{l}\text { I and } \\
\text { II }\end{array}$ & China \\
\hline NCT04352608 & $\begin{array}{l}\text { Safety and immunogenicity } \\
\text { study of inactivated vaccine } \\
\text { for prophylaxis of SARS } \\
\text { CoV-2 infection (COVID-19) }\end{array}$ & $\begin{array}{l}\text { Inactivated SARS-CoV-2 } \\
\text { vaccine }\end{array}$ & Recruiting & $\begin{array}{l}\text { I and } \\
\text { II }\end{array}$ & China \\
\hline NCT04412538 & $\begin{array}{l}\text { Safety and immunogenicity } \\
\text { study of an inactivated } \\
\text { SARS-CoV-2 vaccine for } \\
\text { preventing against COVID-19 }\end{array}$ & $\begin{array}{l}\text { Inactivated SARS-CoV-2 } \\
\text { vaccine }\end{array}$ & Recruiting & $\begin{array}{l}\text { I and } \\
\text { II }\end{array}$ & China \\
\hline NCT04313127 & $\begin{array}{l}\text { Phase I clinical trial of a } \\
\text { COVID-19 vaccine in } 18-60 \\
\text { healthy adults (CTCOVID-19) }\end{array}$ & $\mathrm{Ad} 5-\mathrm{nCoV}$ & $\begin{array}{l}\text { Active, not } \\
\text { recruiting }\end{array}$ & I & China \\
\hline NCT04341389 & $\begin{array}{l}\text { A Phase II Clinical Trial to } \\
\text { Evaluate the Recombinant } \\
\text { Vaccine for COVID-19 } \\
\text { (Adenovirus Vector) } \\
\text { (CTII-nCoV) }\end{array}$ & $\mathrm{Ad} 5-\mathrm{nCoV}$ & $\begin{array}{l}\text { Active, not } \\
\text { recruiting }\end{array}$ & II & China \\
\hline NCT04276896 & $\begin{array}{l}\text { Immunity and safety of } \\
\text { Covid-19 synthetic minigene } \\
\text { vaccine }\end{array}$ & $\begin{array}{l}\text { LV-SMENP-DC vaccine and } \\
\text { antigen-specific CTLs }\end{array}$ & Recruiting & $\begin{array}{l}\text { I and } \\
\text { II }\end{array}$ & China \\
\hline NCT04299724 & $\begin{array}{l}\text { Safety and immunity of } \\
\text { COVID-19 aAPC vaccine }\end{array}$ & Pathogen-specific aAPC & Recruiting & I & China \\
\hline NCT04414267 & $\begin{array}{l}\text { Bacillus } 27 \text { almette-guérin } \\
\text { vaccination to prevent } \\
\text { COVID-19 (ACTIVATEII) }\end{array}$ & $\begin{array}{l}\text { Calmette Guerin bacillus } \\
\text { vaccine }\end{array}$ & Recruiting & IV & Greece \\
\hline
\end{tabular}


Table 4. (Continued)

\begin{tabular}{|c|c|c|c|c|c|}
\hline $\begin{array}{l}\text { NCT/ } \\
\text { registration } \\
\text { number }\end{array}$ & Title & Intervention & $\begin{array}{l}\text { Recruitment } \\
\text { status }\end{array}$ & Phase & Country \\
\hline NCT04445428 & $\begin{array}{l}\text { OPV as potential protection } \\
\text { against COVID-19 }\end{array}$ & Oral polio vaccine (OPV) & $\begin{array}{l}\text { Not yet } \\
\text { recruiting }\end{array}$ & IV & Guinea-Bissau \\
\hline NCT04527575 & $\begin{array}{l}\text { Study of the safety, } \\
\text { reactogenicity and } \\
\text { immunogenicity of } \\
\text { "EpiVacCorona" vaccine for } \\
\text { the prevention of COVID-19 } \\
\text { (EpiVacCorona) }\end{array}$ & $\begin{array}{l}\text { EpiVacCorona (EpiVacCorona } \\
\text { vaccine based on peptide } \\
\text { antigens for the prevention of } \\
\text { COVID-19) }\end{array}$ & $\begin{array}{l}\text { Active, not } \\
\text { recruiting }\end{array}$ & $\begin{array}{l}\text { I and } \\
\text { II }\end{array}$ & Russia \\
\hline NCT04587219 & $\begin{array}{l}\text { The study of } \\
\text { "Gam-COVID-Vac" vaccine } \\
\text { against COVID- } 19 \text { with the } \\
\text { participation of volunteers of } \\
60 \text { years old and older }\end{array}$ & Gam-COVID-Vac & $\begin{array}{l}\text { Not yet } \\
\text { recruiting }\end{array}$ & II & Russia \\
\hline NCT04540393 & $\begin{array}{l}\text { AZD1222 Vaccine for the } \\
\text { Prevention of COVID-19 }\end{array}$ & AZD1222 & $\begin{array}{l}\text { Not yet } \\
\text { recruiting }\end{array}$ & III & Russia \\
\hline NCT04436471 & $\begin{array}{l}\text { An open study of the } \\
\text { safety, tolerability and } \\
\text { immunogenicity of the drug } \\
\text { "Gam-COVID-Vac" vaccine } \\
\text { against COVID-19 }\end{array}$ & Gam-COVID-Vac & Completed & $\begin{array}{l}\text { I and } \\
\text { II }\end{array}$ & Russia \\
\hline NCT04437875 & $\begin{array}{l}\text { An open study of the } \\
\text { safety, tolerability and } \\
\text { immunogenicity of } \\
\text { "Gam-COVID-Vac Lyo" } \\
\text { vaccine against COVID-19 }\end{array}$ & Gam-COVID-Vac Lyo & Completed & $\begin{array}{l}\text { I and } \\
\text { II }\end{array}$ & Russia \\
\hline NCT04527575 & $\begin{array}{l}\text { Study of the safety, } \\
\text { reactogenicity and } \\
\text { immunogenicity of } \\
\text { "EpiVacCorona" vaccine for } \\
\text { the prevention of COVID-19 } \\
\text { (EpiVacCorona) }\end{array}$ & $\begin{array}{l}\text { EpiVacCorona (EpiVacCorona } \\
\text { vaccine based on peptide } \\
\text { antigens for the prevention of } \\
\text { COVID-19) }\end{array}$ & $\begin{array}{l}\text { Active, not } \\
\text { recruiting }\end{array}$ & $\begin{array}{l}\text { I and } \\
\text { II }\end{array}$ & Russia \\
\hline NCT04530396 & $\begin{array}{l}\text { Clinical trial of efficacy, } \\
\text { safety, and immunogenicity } \\
\text { of Gam-COVID-Vac vaccine } \\
\text { against COVID-19 (RESIST) }\end{array}$ & Gam-COVID-Vac & Recruiting & III & Russia \\
\hline NCT04540419 & $\begin{array}{l}\text { Clinical trial of recombinant } \\
\text { novel coronavirus vaccine } \\
\text { (Adenovirus Type } 5 \text { Vector) } \\
\text { against COVID-19 }\end{array}$ & $\begin{array}{l}\text { Recombinant novel } \\
\text { coronavirus vaccine } \\
\text { (adenovirus type } 5 \text { vector)/ } \\
\text { placebo }\end{array}$ & Recruiting & III & Russia \\
\hline NCT04583995 & $\begin{array}{l}\text { A study looking at the } \\
\text { effectiveness, immune } \\
\text { response, and safety of a } \\
\text { COVID- } 19 \text { vaccine in adults } \\
\text { in the United Kingdom }\end{array}$ & $\begin{array}{l}\text { SARS-CoV-2 rS/Matrix } \\
\text { M1-Adjuvant/placebo }\end{array}$ & Recruiting & III & $\begin{array}{l}\text { The United } \\
\text { Kingdom }\end{array}$ \\
\hline NCT04400838 & $\begin{array}{l}\text { Investigating a vaccine against } \\
\text { COVID-19 }\end{array}$ & ChAdO $\times 1 \mathrm{nCoV}-19$ & Recruiting & $\begin{array}{l}\text { II and } \\
\text { III }\end{array}$ & $\begin{array}{l}\text { The United } \\
\text { Kingdom }\end{array}$ \\
\hline
\end{tabular}


Table 4. (Continued)

\begin{tabular}{|c|c|c|c|c|c|}
\hline $\begin{array}{l}\mathrm{NCT} / \\
\text { registration } \\
\text { number }\end{array}$ & Title & Intervention & $\begin{array}{l}\text { Recruitment } \\
\text { status }\end{array}$ & Phase & Country \\
\hline NCT04333732 & $\begin{array}{l}\text { CROWN CORONATION: } \\
\text { COVID-19 research outcomes } \\
\text { worldwide network for } \\
\text { Coronavirus prevention } \\
\text { (CROWN CORONA) }\end{array}$ & $\begin{array}{l}\text { MR or M-M-R II }{ }^{\circledR} \text { vaccine/ } \\
\text { placebo }\end{array}$ & Recruiting & III & $\begin{array}{l}\text { The United } \\
\text { Kingdom }\end{array}$ \\
\hline NCT04324606 & $\begin{array}{l}\text { A study of a candidate } \\
\text { COVID-19 vaccine (COV001) }\end{array}$ & $\begin{array}{l}\text { ChAdO } \times 1 \mathrm{nCoV}-19 / \\
\text { MenACWY vaccine }\end{array}$ & $\begin{array}{l}\text { Active, not } \\
\text { recruiting }\end{array}$ & $\begin{array}{l}\text { I and } \\
\text { II }\end{array}$ & $\begin{array}{l}\text { The United } \\
\text { Kingdom }\end{array}$ \\
\hline NCT04400838 & $\begin{array}{l}\text { Investigating a vaccine against } \\
\text { COVID-19 }\end{array}$ & $\begin{array}{l}\text { ChAdO } \times 1 \mathrm{nCoV}-19 / \\
\text { MenACWY vaccine }\end{array}$ & Recruiting & $\begin{array}{l}\text { II and } \\
\text { III }\end{array}$ & $\begin{array}{l}\text { The United } \\
\text { Kingdom }\end{array}$ \\
\hline NCT04591717 & $\begin{array}{l}\text { Study of the safety of } \\
\text { prophylactic vaccination } \\
\text { with } 2^{\text {nd }} \text { generation } \\
\text { E1/E2B/E3-deleted } \\
\text { adenoviral-COVID-19 in } \\
\text { normal healthy volunteers }\end{array}$ & $\begin{array}{l}\text { hAd5-S-Fusion + N-ETSD } \\
\text { vaccine }\end{array}$ & Recruiting & I & $\begin{array}{l}\text { The United } \\
\text { States }\end{array}$ \\
\hline NCT04563702 & $\begin{array}{l}\text { Safety and Immunogenicity } \\
\text { Trial of an Oral SARS-CoV-2 } \\
\text { Vaccine (VXA-CoV2-1) for } \\
\text { Prevention of COVID-19 in } \\
\text { Healthy Adults }\end{array}$ & VXA-CoV2-1 & Recruiting & I & $\begin{array}{l}\text { The United } \\
\text { States }\end{array}$ \\
\hline NCT04537208 & $\begin{array}{l}\text { Study of recombinant protein } \\
\text { vaccine formulations against } \\
\text { COVID-19 in healthy adults } \\
18 \text { years of age and older }\end{array}$ & SARS-CoV-2 vaccine & Recruiting & $\begin{array}{l}\text { I and } \\
\text { II }\end{array}$ & $\begin{array}{l}\text { The United } \\
\text { States }\end{array}$ \\
\hline NCT04368988 & $\begin{array}{l}\text { Evaluation of the safety } \\
\text { and immunogenicity of a } \\
\text { SARS-CoV-2 rS nanoparticle } \\
\text { vaccine with/without } \\
\text { Matrix-M adjuvant }\end{array}$ & $\begin{array}{l}\text { SARS-CoV-2 rS/Matrix-M } \\
\text { adjuvant/placebo }\end{array}$ & $\begin{array}{l}\text { Active, not } \\
\text { recruiting }\end{array}$ & $\begin{array}{l}\text { I and } \\
\text { II }\end{array}$ & $\begin{array}{l}\text { The United } \\
\text { States }\end{array}$ \\
\hline NCT04336410 & $\begin{array}{l}\text { Safety, tolerability and } \\
\text { immunogenicity of INO- } 4800 \\
\text { for COVID-19 in healthy } \\
\text { volunteers }\end{array}$ & INO-4800 & $\begin{array}{l}\text { Active, not } \\
\text { recruiting }\end{array}$ & I & $\begin{array}{l}\text { The United } \\
\text { States }\end{array}$ \\
\hline NCT04540185 & $\begin{array}{l}\text { A phase } 3 \text { randomized } \\
\text { double-blind efficacy and } \\
\text { safety study of oral polio } \\
\text { vaccine and NA-831 for } \\
\text { Covid-19 (OPV-NA831) }\end{array}$ & Oral polio vaccine & $\begin{array}{l}\text { Enrolling by } \\
\text { invitation }\end{array}$ & III & $\begin{array}{l}\text { The United } \\
\text { States }\end{array}$ \\
\hline NCT04498247 & $\begin{array}{l}\text { A study to assess } \\
\text { safety, tolerability, and } \\
\text { immunogenicity of V591 } \\
\text { (COVID-19 vaccine) } \\
\text { in healthy participants } \\
\text { (V591-001) }\end{array}$ & V591/placebo & Recruiting & $\begin{array}{l}\text { I and } \\
\text { II }\end{array}$ & $\begin{array}{l}\text { The United } \\
\text { States }\end{array}$ \\
\hline NCT04386252 & $\begin{array}{l}\text { Phase Ib-II trial of dendritic } \\
\text { cell vaccine to prevent } \\
\text { COVID-19 in adults }\end{array}$ & AV-COVID-19 & $\begin{array}{l}\text { Not yet } \\
\text { recruiting }\end{array}$ & $\begin{array}{l}\text { I and } \\
\text { II }\end{array}$ & $\begin{array}{l}\text { The United } \\
\text { States }\end{array}$ \\
\hline
\end{tabular}


Table 4. (Continued)

\begin{tabular}{|c|c|c|c|c|c|}
\hline $\begin{array}{l}\mathrm{NCT} / \\
\text { registration } \\
\text { number }\end{array}$ & Title & Intervention & $\begin{array}{l}\text { Recruitment } \\
\text { status }\end{array}$ & Phase & Country \\
\hline NCT04283461 & $\begin{array}{l}\text { Safety and immunogenicity } \\
\text { study of 2019-nCoV vaccine } \\
\text { (mRNA-1273) for prophylaxis } \\
\text { of SARS-CoV-2 Infection } \\
\text { (COVID-19) }\end{array}$ & mRNA-1273 & $\begin{array}{l}\text { Active, not } \\
\text { recruiting }\end{array}$ & I & $\begin{array}{l}\text { The United } \\
\text { States }\end{array}$ \\
\hline NCT04334980 & $\begin{array}{l}\text { Evaluating the safety, } \\
\text { tolerability and } \\
\text { immunogenicity of } \\
\text { bacTRL-Spike vaccine for } \\
\text { prevention of COVID-19 }\end{array}$ & bacTRL-Spike & $\begin{array}{l}\text { Not yet } \\
\text { recruiting }\end{array}$ & I & $\begin{array}{l}\text { The United } \\
\text { States }\end{array}$ \\
\hline NCT04368728 & $\begin{array}{l}\text { Study to describe the safety, } \\
\text { tolerability, immunogenicity, } \\
\text { and efficacy of RNA vaccine } \\
\text { candidates against COVID-19 } \\
\text { in healthy adults }\end{array}$ & $\begin{array}{l}\text { BNT162b1/BNT162b2/ } \\
\text { BNT162b3 }\end{array}$ & Recruiting & $\begin{array}{l}\text { II and } \\
\text { III }\end{array}$ & $\begin{array}{l}\text { The United } \\
\text { States }\end{array}$ \\
\hline NCT04336410 & $\begin{array}{l}\text { Safety, tolerability and } \\
\text { immunogenicity of INO- } 4800 \\
\text { for COVID-19 in healthy } \\
\text { volunteers }\end{array}$ & INO-4800 & $\begin{array}{l}\text { Active, not } \\
\text { recruiting }\end{array}$ & I & $\begin{array}{l}\text { The United } \\
\text { States }\end{array}$ \\
\hline NCT04405076 & $\begin{array}{l}\text { Dose-confirmation } \\
\text { study to evaluate the } \\
\text { safety, reactogenicity, } \\
\text { and immunogenicity of } \\
\text { mRNA-1273 COVID-19 } \\
\text { vaccine in adults aged } \\
18 \text { years and older }\end{array}$ & mRNA-1273 & $\begin{array}{l}\text { Active, not } \\
\text { recruiting }\end{array}$ & II & $\begin{array}{l}\text { The United } \\
\text { States }\end{array}$ \\
\hline NCT04470427 & $\begin{array}{l}\text { A study to evaluate efficacy, } \\
\text { safety, and immunogenicity of } \\
\text { mRNA-1273 vaccine in adults } \\
\text { aged } 18 \text { years and older to } \\
\text { prevent COVID-19 }\end{array}$ & mRNA-1273 & Recruiting & III & $\begin{array}{l}\text { The United } \\
\text { States }\end{array}$ \\
\hline NCT03305341 & $\begin{array}{l}\text { Discovery stage } \\
\text { (proof-of-concept) COVID-19 } \\
\text { antigen presentation } \\
\text { therapeutic vaccine } \\
\text { (COVID-19-AP) }\end{array}$ & $\begin{array}{l}\text { COVID-19 therapeutic vaccine } \\
\text { - Nucleocapsid-GM-CSF } \\
\text { Protein Lactated Ringer's } \\
\text { Injection }\end{array}$ & $\begin{array}{l}\text { Active, not } \\
\text { recruiting }\end{array}$ & Early I & $\begin{array}{l}\text { The United } \\
\text { States }\end{array}$ \\
\hline NCT04025580 & $\begin{array}{l}\text { Systems analyses of the } \\
\text { immune response to the } \\
\text { seasonal influenza vaccine }\end{array}$ & Seasonal influenza vaccine & Recruiting & II & $\begin{array}{l}\text { The United } \\
\text { States }\end{array}$ \\
\hline
\end{tabular}

\section{Conclusion}

Despite a considerable amount of research and significant progress, the COVID-19 pandemic has not been effectively controlled worldwide yet and has become the greatest pandemic in the $21^{\text {st }}$ century. Several drugs are currently used in clinical trials, but the safety and efficacy need to be further investigated in larger and diverse populations as well as in different stages. Potential drug and vaccines still need to be studied before being progressed to clinical trials. Notably, vaccine plays a key role in the prevention and the control of transmission of COVID-19. Development of vaccines, rapid point-of-care diagnostic tools and effective targeted treatments are among the high 
priorities of research in this area. These are attracting substantial attention and funding. In addition, the virological characteristics of SARS-CoV-2 should be explored more thoroughly so that more potential therapeutic targets can be discovered, leading to safer, and more effective treatment to COVID-19.

\section{Funding}

We would like to acknowledge the National Breast Cancer Foundation Research fellowship and grant to Dr. Pegah Varamini (PF-16-007).

\section{Conflicts of interest}

Authors have no conflict of interest to declare.

\section{References}

[1] Yang, F.; Shi, S.; Zhu, J.; Shi, J.; Dai, K.; Chen, X. Analysis of 92 Deceased Patients with COVID-19. J. Med. Virol., 2020, 11, 2511-5.

[2] Zhu, J.; Ji, P.; Pang, J.; Zhong, Z.; Li, H.; He, C.; Zhang, J.; Zhao, C. Clinical Characteristics of 3,062 COVID-19 Patients: A Meta-analysis. J. Med. Virol., 2020, 92, 1902-14.

[3] Zhu, F.C.; Guan, X.H.; Li, Y.H.; Huang, J.Y.; Jiang, T.; Hou, L.H.; Li, J.X.; Yang, B.F.; Wang, L.; Wang, W.J.; Wu, S.P.; Wang, Z.; Wu, X.H.; Xu, J.J.; Zhang, Z.; Jia, S.Y.; Wang, B.S.; Hu, Y.; Liu, J.J.; Zhang, J.; Qian, X.A.; Li, Q.; Pan, H.X.; Jiang, H.D.; Deng, P.; Gou, J.B.; Wang, X.W.; Wang, X.H.; Chen, W. Immunogenicity and Safety of a Recombinant Adenovirus Type5-vectored COVID-19 Vaccine in Healthy Adults Aged 18 Years or Older: A Randomised, Double-blind, Placebo-controlled, Phase 2 Trial. Lancet, 2020, 396(10249), 479-88.

[4] Chen, Y.; Liu, Q.; Guo, D. Emerging Coronaviruses: Genome Structure, Replication, and Pathogenesis. J. Med. Virol. 2020, 92(4), 418-23.

[5] Fan, C.; Li, K.; Ding, Y.; Lu, W.; Wang, J. ACE2 Expression in Kidney and Testis May Cause Kidney and Testis Damage After 2019-nCoV Infection. medRxiv, 2020.

[6] Wan, S.; Xiang, Y.; Fang, W.; Zheng, Y.; Li, B.; Hu, Y.; Lang, C.; Huang, D.; Sun, Q.; Xiong, Y.; Huang, X.; Lv, J.; Luo, Y.; Shen, L.; Yang, H.; Huang, G.; Yang, R. Clinical features and treatment of COVID-19 patients in northeast Chongqing. J. Med. Virol., 2020, 92(7), 797-806.

[7] Wong, C.K.; Lam, C.W.; Wu, A.K.; Ip, W.K.; Lee, N.L.; Chan, I.H.; Lit, L.C.; Hui, D.S.; Chan, M.H.; Chung, S.S.; Sung, J.J. Plasma Inflammatory Cytokines and Chemokines in Severe Acute Respiratory Syndrome. Clin. Exp. Immunol., 2004, 136(1), 95-103.

[8] Zhang, H.; Kang, Z.; Gong, H.; Xu, D.; Wang, J.; Li, Z.; Cui, X.; Xiao, J.; Meng, T.; Zhou, W.; Liu, J.; Xu, H. The Digestive System is a Potential Route of 2019-nCov Infection: A Bioinformatics Analysis Based on Single-Cell Transcriptomes. bioRxiv, 2020.

[9] Guan, W.J.; Liang, W.H.; Zhao, Y.; Liang, H.R.; Chen, Z.S.; Li, Y.M.; Liu, X.Q.; Chen, R.C.; Tang, C.L.; Wang, T.; Ou, C.Q.; Li, L.; Chen, P.Y.; Sang, L.; Wang, W.; Li, J.F.; Li, C.C.; Ou, L.M.; Cheng, B.; Xiong, S.; Ni, Z.Y.; Xiang, J.; Hu, Y.; Liu, L.; Shan, H.; Lei, C.L.; Peng, Y.X.; Wei, L.; Liu, Y.; Hu, Y.H.; Peng, P.; Wang, J.M.; Liu, J.Y.; Chen, Z.; Li, G.; Zheng, Z.J.; Qiu, S.Q.; Luo, J.; Ye, C.J.; Zhu, S.Y.; Cheng, L.L.; Ye, F.; Li, S.Y.; Zheng, J.P.; Zhang, N.F.; Zhong, N.S.; He, J.X.; China Medical Treatment Expert Group for COVIS-19. Comorbidity and its Impact on 1590 Patients with Covid-19 in China: A Nationwide Analysis. Eur. Respir. J., 2020, 55(5), 2000547.
[10] General Office of the National Health and Health Commission. Diagnosis and Treatment Protocol for Novel Coronavirus Pneumonia (Trial Version 8). Available from: http://www.nhc.gov. cn/yzygj/s7653p/202008/0a7bdf12bd4b46e5bd28ca7f9a7f5e5a. shtml. [Last accessed on 2020 Oct 01].

[11] Xue, H.; Jin, Z. The Appropriate Position of Radiology in COVID-19 Diagnosis and Treatment-Current Status and Opinion from China. Chin. J. Acad. Radiol, 2020, 2020, 1-3.

[12] Pata, D.; Valentini, P.; De Rose, C.; De Santis, R.; Morello, R.; Buonsenso, D. Chest Computed Tomography and Lung Ultrasound Findings in COVID-19 Pneumonia: A Pocket Review for Nonradiologists. Front. Med. (Lausanne), 2020, 7, 375.

[13] Lijia, S.; Lihong, S.; Huabin, W.; Xiaoping, X.; Xiaodong, L.; Yixuan, Z.; Pin, H.; Yina, X.; Xiaoyun, S.; Junqi, W. Serological Chemiluminescence Immunoassay for the Diagnosis of SARSCoV-2 Infection. J. Clin. Lab. Anal., 2020, 34(10), e23466.

[14] Huang, Z.; Jiang, Y.; Chen, J.; Zhou, Y. Inhibitors of the Reninangiotensin System: The Potential Role in the Pathogenesis of COVID-19. Cardiol. J., 2020, 27(2), 171-4.

[15] Imai, Y.; Kuba, K.; Rao, S.; Huan, Y.; Guo, F.; Guan, B.; Yang, P.; Sarao, R.; Wada, T.; Leong-Poi, H.; Crackower, M.A.; Fukamizu, A.; Hui, C.C.; Hein, L.; Uhlig, S.; Slutsky, A.S.; Jiang, C.; Penninger, J.M. Angiotensin-converting Enzyme 2 Protects from Severe Acute Lung Failure. Nature, 2005, 436(7047), 112-6.

[16] Kuba, K.; Imai, Y.; Rao, S.; Gao, H.; Guo, F.; Guan, B.; Huan, Y.; Yang, P.; Zhang, Y.; Deng, W.; Bao, L.; Zhang, B.; Liu, G.; Wang, Z.; Chappell, M.; Liu, Y.; Zheng, D.; Leibbrandt, A.; Wada, T.; Slutsky, A.S.; Liu, D.; Qin, C.; Jiang, C.; Penninger, J.M. A Crucial Role of Angiotensin Converting Enzyme 2 (ACE2) in SARS Coronavirus-induced Lung Injury. Nat. Med., 2005, 11(8), 875-9.

[17] Crackower, M.A.; Sarao, R.; Oudit, G.Y.; Yagil, C.; Kozieradzki, I.; Scanga, S.E.; Oliveira-dos-Santos, A.J.; da Costa, J.; Zhang, L.; Pei, Y.; Scholey, J.; Ferrario, C.M.; Manoukian, A.S.; Chappell, M.C.; Backx, P.H.; Yagil, Y.; Penninger, J.M. Angiotensin-converting Enzyme 2 is an Essential Regulator of Heart Function. Nature, 2002, 417(6891), 822-8.

[18] Xu, X.; Chen, P.; Wang, J.; Feng, J.; Zhou, H.; Li, X.; Zhong, W.; Hao, P. Evolution of the Novel Coronavirus from the Ongoing Wuhan Outbreak and Modeling of its Spike Protein for Risk of Human Transmission. Sci. Chin. Life Sci., 2020, 63(3), 457-60.

[19] Wevers, B.A.; van der Hoek, L. Renin-angiotensin System in Human Coronavirus Pathogenesis. Future Virol., 2010, 5(2), 145-61.

[20] Huentelman, M.J.; Zubcevic, J.; Hernandez Prada, J.A.; Xiao, X.; Dimitrov, D.S.; Raizada, M.K.; Ostrov, D.A. Structure-based Discovery of a Novel Angiotensin-converting Enzyme 2 Inhibitor. Hypertension (Dallas, Tex. : 1979), 2004, 44(6), 903-6.

[21] Bonow, R.O.; Fonarow, G.C.; O'Gara, P.T.; Yancy, C.W. Association of Coronavirus Disease 2019 (COVID-19) With Myocardial Injury and Mortality. JAMA Cardiol., 2020, 5(7), 751-3.

[22] Kwong, J.C.; Schwartz, K.L.; Campitelli, M.A. Acute Myocardial Infarction after Laboratory-Confirmed Influenza Infection. N. Engl. J. Med., 2018, 378(26), 2540-1.

[23] Oudit, G.Y.; Kassiri, Z.; Jiang, C.; Liu, P.P.; Poutanen, S.M.; Penninger, J.M.; Butany, J. SARS-coronavirus Modulation of Myocardial ACE2 Expression and Inflammation in Patients with SARS. Eur. J. Clin. Investig., 2009, 39(7), 618-25.

[24] Liu, P.P.; Blet, A.; Smyth, D.; Li, H. The Science Underlying COVID-19: Implications for the Cardiovascular System. Circulation, 2020, 142(1), 68-78.

[25] Drucker, D.J. Coronavirus Infections and Type 2 Diabetes-shared Pathways with Therapeutic Implications. Endocr. Rev., 2020, 41(3), bnaa011.

[26] Yang, J.K.; Lin, S.S.; Ji, X.J.; Guo, L.M. Binding of SARS Coronavirus to its Receptor Damages Islets and Causes Acute Diabetes. Acta Diabetol., 2010, 47(3), 193-9.

[27] Booth, C.M.; Matukas, L.M.; Tomlinson, G.A.; Rachlis, A.R.; Rose, D.B.; Dwosh, H.A.; Walmsley, S.L.; Mazzulli, T.; Avendano, M.; Derkach, P.; Ephtimios, I.E.; Kitai, I.; 
Mederski, B.D.; Shadowitz, S.B.; Gold, W.L.; Hawryluck, L.A.; Rea, E.; Chenkin, J.S.; Cescon, D.W.; Poutanen, S.M.; Detsky, A.S. Clinical Features and Short-term Outcomes of 144 Patients with SARS in the Greater Toronto Area. JAMA, 2003, 289(21), 2801-9.

[28] Alqahtani, F.Y.; Aleanizy, F.S.; Ali El Hadi Mohamed, R.; Alanazi, M.S.; Mohamed, N.; Alrasheed, M.M.; Abanmy, N.; Alhawassi, T. Prevalence of Comorbidities in Cases of Middle East Respiratory Syndrome Coronavirus: A Retrospective Study. Epidemiol. Infect., 2018, 47, 1-5.

[29] Guo, W.; Li, M.; Dong, Y.; Zhou, H.; Zhang, Z.; Tian, C.; Qin, R.; Wang, H.; Shen, Y.; Du, K.; Zhao, L.; Fan, H.; Luo, S.; Hu, D. Diabetes is a Risk Factor for the Progression and Prognosis of COVID-19. Diabetes Metab. Res. Rev., 2020, 2020, e3319.

[30] Chow, N.; Fleming-Dutra, K.; Gierke, R.; Hall, A.; Hughes, M.; Pilishvili, T.; Ritchey, M.; Roguski, K.; Skoff, T.; Ussery, E. Preliminary estimates of the prevalence of selected underlying health conditions among patients with coronavirus disease 2019 United States, February 12-March 28, 2020. MMWR Morb. Mortal. Wkly. Rep. 2020, 69(13), 382-6.

[31] Seshasai, S.R.K.; Kaptoge, S.; Thompson, A.; Di Angelantonio, E.; Gao, P.; Sarwar, N.; Whincup, P.H.; Mukamal, K.J.; Gillum, R.F.; Holme, I.; Njolstad, I.; Fletcher, A.; Nilsson, P.; Lewington, S.; Collins, R.; Gudnason, V.; Thompson, S.G.; Sattar, N.; Selvin, E.; Hu, F.B.; Danesh, J. Diabetes Mellitus, Fasting Glucose, and Risk of Cause-specific Death. New Engl. J. Med., 2011, 364(9), 829-41.

[32] Jin, X.; Lian, J.S.; Hu, J.H.; Gao, J.; Zheng, L.; Zhang, Y.M.; Hao, S.R.; Jia, H.Y.; Cai, H.; Zhang, X.L.; Yu, G.D.; Xu, K.J.; Wang, X.Y.; Gu, J.Q.; Zhang, S.Y.; Ye, C.Y.; Jin, C.L.; Lu, Y.F.; Yu, X.; Yu, X.P.; Huang, J.R.; Xu, K.L.; Ni, Q.; Yu, C.B.; Zhu, B.; Li, Y.T.; Liu, J.; Zhao, H.; Zhang, X.; Yu, L.; Guo, Y.Z.; Su, J.W.; Tao, J.J.; Lang, G.J.; Wu, X.X.; Wu, W.R.; Qv, T.T.; Xiang, D.R.; Yi, P.; Shi, D.; Chen, Y.; Ren, Y.; Qiu, Y.Q.; Li, L.J.; Sheng, J.; Yang, Y. Epidemiological, Clinical and Virological Characteristics of 74 Cases of Coronavirus-infected Disease 2019 (COVID-19) with Gastrointestinal Symptoms. Gut, 2020, 69(6), 1002-9.

[33] Lighter, J.; Phillips, M.; Hochman, S.; Sterling, S.; Johnson, D.; Francois, F.; Stachel, A. Obesity in Patients Younger than 60 Years is a Risk Factor for Covid-19 Hospital Admission. Clin. Infect. Dis., 2020, 71(15), 896-7.

[34] Porfidia, A.; Pola, R. Venous Thromboembolism in COVID-19 Patients. J. Thromb. Haemost., 2020, 18(6), 1516-7.

[35] Tang, N.; Bai, H.; Chen, X.; Gong, J.; Li, D.; Sun, Z. Anticoagulant Treatment is Associated with Decreased Mortality in Severe Coronavirus Disease 2019 Patients with Coagulopathy. J. Thromb. Haemost., 2020, 18(5), 1094-9.

[36] Li, X.; Dai, T.; Wang, H.; Shi, J.; Yuan, W.; Li, J.; Chen, L.; Zhang, T.; Zhang, S.; Kong, Y.; Yue, N.; Shi, H.; He, Y.; Hu, H.; Liu, F.; Yang, C. Clinical Analysis of Suspected Novel Coronavirus Pneumonia Patients with Anxiety and Depression. Zhejiang Da Xue Xue Bao Yi Xue Ban, 2020, 49(1), 203-8.

[37] Henry, B.M.; Lippi, G. Chronic Kidney Disease is Associated with Severe Coronavirus Disease 2019 (COVID-19) Infection. Int. Urol. Nephrol., 2020, 52(6), 1193-4.

[38] Wong, S.H.; Lui, R.N.; Sung, J.J. Covid-19 and the Digestive System. J. Gastroenterol. Hepatol., 2020, 35(5), 744-8.

[39] Cava, C.; Bertoli, G.; Castiglioni, I. In Silico Discovery of Candidate Drugs against Covid-19. Viruses, 2020, 12(4), 404.

[40] Elfiky, A.A. Ribavirin, Remdesivir, Sofosbuvir, Galidesivir, and Tenofovir against SARS-CoV-2 RNA Dependent RNA Polymerase (RdRp): A Molecular Docking Study. Life Sci., 2020, 253, 117592. Hall, D.C. Jr.; Ji, H.F. A Search for Medications to Treat COVID-19 via In Silico Molecular Docking Models of the SARS-CoV-2 Spike Glycoprotein and 3CL Protease. Travel Med. Infect. Dis., 2020, 35, 101646.

[42] Liu, S.; Zheng, Q.; Wang, Z. Potential Covalent Drugs Targeting the Main Protease of the SARS-CoV-2 Coronavirus. Bioinformatics, 2020, 36(11), 3295-8.

[43] Savarino, A.; Boelaert, J.R.; Cassone, A.; Majori, G.; Cauda, R. Effects of Chloroquine on Viral Infections: An Old Drug Against
Today's Diseases. Lancet Infect. Dis., 2003, 3(11), 722-7.

Zhou, D.; Dai, S.M.; Tong, Q. COVID-19: A Recommendation to Examine the Effect of Hydroxychloroquine in Preventing Infection and Progression. J. Antimicrob. Chemother., 2020, 75(7), 1667-70.

[45] Devaux, C.A.; Rolain, J.M.; Colson, P.; Raoult, D. New Insights on the Antiviral Effects of Chloroquine Against Coronavirus: What to Expect for COVID-19? Int. J. Antimicrob. Agents, 2020, 105938.

[46] Yao, X.; Ye, F.; Zhang, M.; Cui, C.; Huang, B.; Niu, P.; Liu, X.; Zhao, L.; Dong, E.; Song, C.; Zhan, S.; Lu, R.; Li, H.; Tan, W.; Liu, D. In Vitro Antiviral Activity and Projection of Optimized Dosing Design of Hydroxychloroquine for the Treatment of Severe Acute Respiratory Syndrome Coronavirus 2 (SARS-CoV-2). Clin. Infect. Dis., 2020, 71(15), 732-9.

[47] Rossignol, J.F. Nitazoxanide, a New Drug Candidate for the Treatment of Middle East Respiratory Syndrome Coronavirus. J. Infect. Public Health, 2016, 9(3), 227-30.

[48] Wang, M.; Cao, R.; Zhang, L.; Yang, X.; Liu, J.; Xu, M.; Shi, Z.; $\mathrm{Hu}, \mathrm{Z}$;; Zhong, W.; Xiao, G. Remdesivir and Chloroquine Effectively Inhibit the Recently Emerged Novel Coronavirus (2019-nCoV) In Vitro. Cell Res., 2020, 30(3), 269-71.

[49] Lu, C.C.; Chen, M.Y.; Chang, Y.L. Potential Therapeutic Agents Against COVID-19: What we know so Far. J. Chin. Med. Assoc., 2020, 83(6), 534-6

[50] Gautret, P.; Lagier, J.C.; Parola, P.; Hoang, V.T.; Meddeb, L.; Mailhe, M.; Doudier, B.; Courjon, J.; Giordanengo, V.; Vieira, V.E.; Dupont, H.T.; Honore, S.; Colson, P.; Chabriere, E.; La Scola, B.; Rolain, J.M.; Brouqui, P.; Raoult, D. Hydroxychloroquine and Azithromycin as a Treatment of COVID-19: Results of an Openlabel Non-randomized Clinical Trial. Int. J. Antimicrob. Agents, 2020, 56(1), 105949.

[51] Gao, J.; Tian, Z.; Yang, X. Breakthrough: Chloroquine Phosphate has Shown Apparent Efficacy in Treatment of COVID-19 Associated Pneumonia in Clinical Studies. Biosci. Trends, 2020, 14(1), 72-3.

[52] Millan-Onate, J.; Millan, W.; Mendoza, L.A.; Sanchez, C.G.; Fernandez-Suarez, H.; Bonilla-Aldana, D.K.; RodriguezMorales, A.J. Successful Recovery of COVID-19 Pneumonia in a Patient from Colombia after Receiving Chloroquine and Clarithromycin. Ann. Clin. Microbiol. Antimicrob., 2020, 19(1), 16.

[53] Tang, W.; Cao, Z.; Han, M.; Wang, Z.; Chen, J.; Sun, W.; Wu, Y.; Xiao, W.; Liu, S.; Chen, E.; Chen, W.; Wang, X.; Yang, J.; Lin, J.; Zhao, Q.; Yan, Y.; Xie, Z.; Li, D.; Yang, Y.; Liu, L.; Qu, J.; Ning, G.; Shi, G.; Xie, Q. Hydroxychloroquine in Patients with Mainly Mild to Moderate Coronavirus Disease 2019: Open Label, Randomised Controlled Trial. BMJ, 2020, 369, m1849.

[54] Borba, M.G.S.; Val, F.F.A.; Sampaio, V.S.; Alexandre, M.A.A.; Melo, G.C.; Brito, M.; Mourao, M.P.G.; Brito-Sousa, J.D.; Baiada-Silva, D.; Guerra, M.V.F.; Hajjar, L.A.; Pinto, R.C.; Balieiro, A.A.S.; Pacheco, A.G.F.; Santos, J.D.O. Jr.; Naveca, F.G.; Xavier, M.S.; Siqueira, A.M.; Schwarzbold, A.; Croda, J.; Nogueira, M.L.; Romero, G.A.S.; Bassat, Q.; Fontes, C.J.; Albuquerque, B.C.; Daniel-Ribeiro, C.T.; Monteiro, W.M.; Lacerda, M.V.G.; CloroCovid, T. Effect of High vs Low Doses of Chloroquine Diphosphate as Adjunctive Therapy for Patients Hospitalized With Severe Acute Respiratory Syndrome Coronavirus 2 (SARS-CoV-2) Infection: A Randomized Clinical Trial. JAMA Netw Open, 2020, 3(4), e208857.

[55] Jiang, S.; Li. L.; Ru, R.; Zhang, C.; Rao, Y.; Lin, B.; Wang, R.; Chen, N.; Wang, X.; Cai, H.; Sheng, J.; Zhou, J.; Lu, X.; Qiu, Y. Pharmaceutical Care for Severe and Critically Ill Patients with Corona Virus Disease 2019 (COVID-19). Zhejiang Da Xue Xue Bao Yi Xue Ban, 2020, 49(1), 158-69.

[56] Singh, A.K.; Singh, A.; Shaikh, A.; Singh, R.; Misra, A. Chloroquine and Hydroxychloroquine in the Treatment of COVID-19 with or Without Diabetes: A Systematic Search and a Narrative Review with a Special Reference to India and Other Developing Countries. Diabetes Metab. Syndr., 2020, 14(3), 241-6.

[57] Sheahan, T.P.; Sims, A.C.; Graham, R.L.; Menachery, V.D.; Gralinski, L.E.; Case, J.B.; Leist, S.R.; Pyrc, K.; Feng, J.Y.; 
Trantcheva, I.; Bannister, R.; Park, Y.; Babusis, D.; Clarke, M.O.; Mackman, R.L.; Spahn, J.E.; Palmiotti, C.A.; Siegel, D.; Ray, A.S.; Cihlar, T.; Jordan, R.; Denison, M.R.; Baric, R.S. Broadspectrum Antiviral GS-5734 Inhibits Both Epidemic and Zoonotic Coronaviruses. Sci. Transl. Med., 2017, 9(396), eaal3653.

[58] Gordon, C.J.; Tchesnokov, E.P.; Feng, J.Y.; Porter, D.P.; Gotte, M. The Antiviral Compound Remdesivir Potently Inhibits RNAdependent RNA Polymerase from Middle East Respiratory Syndrome Coronavirus. J. Biol. Chem., 2020, 295(15), 4773-9.

[59] Warren, T.K.; Jordan, R.; Lo, M.K.; Ray, A.S.; Mackman, R.L.; Soloveva, V.; Siegel, D.; Perron, M.; Bannister, R.; Hui, H. C.; Larson, N.; Strickley, R.; Wells, J.; Stuthman, K.S.; Van Tongeren, S.A.; Garza, N.L.; Donnelly, G.; Shurtleff, A.C.; Retterer, C.J.; Gharaibeh, D.; Zamani, R.; Kenny, T.; Eaton, B.P.; Grimes, E.; Welch, L.S.; Gomba, L.; Wilhelmsen, C.L.; Nichols, D.K.; Nuss, J.E.; Nagle, E.R.; Kugelman, J.R.; Palacios, G.; Doerffler, E.; Neville, S.; Carra, E.; Clarke, M.O.; Zhang, L.; Lew, W.; Ross, B.; Wang, Q.; Chun, K.; Wolfe, L.; Babusis, D.; Park, Y.; Stray, K.M.; Trancheva, I.; Feng, J.Y.; Barauskas, O.; Xu, Y.; Wong, P.; Braun, M.R.; Flint, M.; McMullan, L.K.; Chen, S.S.; Fearns, R.; Swaminathan, S.; Mayers, D.L.; Spiropoulou, C.F.; Lee, W.A.; Nichol, S.T.; Cihlar, T.; Bavari, S. Therapeutic Efficacy of the Small Molecule GS-5734 against Ebola virus in Rhesus Monkeys. Nature, 2016, 531(7594), 381-5.

[60] Sheahan, T.P.; Sims, A.C.; Leist, S.R.; Schäfer, A.; Won, J.; Brown, A.J.; Montgomery, S.A.; Hogg, A.; Babusis, D.; Clarke, M.O.; Spahn, J.E.; Bauer, L.; Sellers, S.; Porter, D.; Feng, J.Y.; Cihlar, T.; Jordan, R.; Denison, M.R.; Baric, R.S. Comparative Therapeutic Efficacy of Remdesivir and Combination Lopinavir, Ritonavir, and Interferon Beta Against MERS-CoV. Nat. Commun., 2020, 11(1), 222.

[61] Wang, Y.; Zhang, D.; Du, G.; Du, R.; Zhao, J.; Jin, Y.; Fu, S.; Gao, L.; Cheng, Z.; Lu, Q.; Hu, Y.; Luo, G.; Wang, K.; Lu, Y.; Li, H.; Wang, S.; Ruan, S.; Yang, C.; Mei, C.; Wang, Y.; Ding, D.; Wu, F.; Tang, X.; Ye, X.; Ye, Y.; Liu, B.; Yang, J.; Yin, W.; Wang, A.; Fan, G.; Zhou, F.; Liu, Z.; Gu, X.; Xu, J.; Shang, L.; Zhang, Y.; Cao, L.; Guo, T.; Wan, Y.; Qin, H.; Jiang, Y.; Jaki, T.; Hayden, F.G.; Horby, P.W.; Cao, B.; Wang, C. Remdesivir in Adults with Severe COVID-19: A Randomised, Double-blind, Placebo-controlled, Multicentre Trial. Lancet, 2020, 395, 1569-78.

[62] Antinori, S.; Cossu, M.V.; Ridolfo, A.L.; Rech, R.; Bonazzetti, C.; Pagani, G.; Gubertini, G.; Coen, M.; Magni, C.; Castelli, A.; Borghi, B.; Colombo, R.; Giorgi, R.; Angeli, E.; Mileto, D.; Milazzo, L.; Vimercati, S.; Pellicciotta, M.; Corbellino, M.; Torre, A.; Rusconi, S.; Oreni, L.; Gismondo, M.R.; Giacomelli, A.; Meroni, L.; Rizzardini, G.; Galli, M. Compassionate Remdesivir Treatment of Severe Covid-19 Pneumonia in Intensive Care Unit (ICU) and Non-ICU Patients: Clinical Outcome and Differences in Post-treatment Hospitalisation Status. Pharmacol. Res., 2020, 158, 104899.

[63] Dong, L.; Hu, S.; Gao, J. Discovering Drugs to Treat Coronavirus Disease 2019 (COVID-19). Drug Discov. Ther., 2020, 14(1), 58-60.

[64] Zhu, Z.; Lu, Z.; Xu, T.; Chen, C.; Yang, G.; Zha, T.; Lu, J.; Xue, Y. Arbidol Monotherapy is Superior to Lopinavir/Ritonavir in Treating COVID-19. J. Infect., 2020, 81(1), e21-3.

[65] Deng, L.; Li, C.; Zeng, Q.; Liu, X.; Li, X.; Zhang, H.; Hong, Z.; Xia, J. Arbidol Combined with LPV/r Versus LPV/r Alone Against Corona Virus Disease 2019: A Retrospective Cohort Study. J. Infect., 2020, 81(1), e1-5.

[66] Xu, K.; Cai, H.; Shen, Y.; Ni, Q.; Chen, Y.; Hu, S.; Li, J.; Wang, H.; Yu, L.; Huang, H.; Qiu, Y.; Wei, G.; Fang, Q.; Zhou, J.; Sheng, J.; Liang, T.; Li, L. Management of Corona Virus Disease-19 (COVID-19): The Zhejiang Experience. Zhejiang Da Xue Xue Bao Yi Xue Ban, 2020, 49(1), 147-57.

[67] Chu, C.M.; Cheng, V.C.; Hung, I.F.; Wong, M.M.; Chan, K.H.; Chan, K.S.; Kao, R.Y.; Poon, L.L.; Wong, C.L.; Guan, Y.; Peiris, J.S.; Yuen, K.Y. Role of Lopinavir/Ritonavir in the Treatment of SARS: Initial Virological and Clinical Findings. Thorax, 2004, 59(3), 252-6.
[68] de Wilde, A.H.; Jochmans, D.; Posthuma, C.C.; ZevenhovenDobbe, J.C.; van Nieuwkoop, S.; Bestebroer, T.M.; van den Hoogen, B.G.; Neyts, J.; Snijder, E.J. Screening of an FDAApproved Compound Library Identifies Four Small-Molecule Inhibitors of Middle East Respiratory Syndrome Coronavirus Replication in Cell Culture. Antimicrob. Agents Chemother., 2014, 58(8), 4875-84.

[69] Yao, T.T.; Qian, J.D.; Zhu, W.Y.; Wang, Y.; Wang, G.Q. A Systematic Review of Lopinavir Therapy for SARS Coronavirus and MERS Coronavirus-A Possible Reference for Coronavirus Disease-19 Treatment Option. J. Med. Virol., 2020, 92(6), 556-63.

[70] Choy, K.T.; Wong, A.Y.L.; Kaewpreedee, P.; Sia, S.F.; Chen, D.; Hui, K.P.Y;; Chu, D.K.W.; Chan, M.C.W.; Cheung, P.P.H.; Huang, X.; Peiris, M.; Yen, H.L. Remdesivir, Lopinavir, Emetine, and Homoharringtonine Inhibit SARS-CoV-2 Replication In Vitro. Antiviral Res., 2020, 178, 104786.

[71] Jun, L.; Tao, Z.; Qibin, W.; Yongcheng, D.; Zizhong, Y. Safety Analysis of Lopinavir/Ritonavir Tablets in 40 Hospitalized Patients with Coronavirus Disease 2019. Chin. J. Hosp. Pharm., 2020, 40(10), 1086-8.

[72] Nakamura, K.; Hikone, M.; Shimizu, H.; Kuwahara, Y.; Tanabe, M.; Kobayashi, M.; Ishida, T.; Sugiyama, K.; Washino, T.; Sakamoto, N.; Hamabe, Y. A Sporadic COVID-19 Pneumonia Treated with Extracorporeal Membrane Oxygenation in Tokyo, Japan: A Case Report. J. Infect. Chemother., 2020, 26(7), 756-61.

[73] Cao, B.; Wang, Y.; Wen, D.; Liu, W.; Wang, J.; Fan, G.; Ruan, L.; Song, B.; Cai, Y.; Wei, M.; Li, X.; Xia, J.; Chen, N.; Xiang, J.; Yu, T.; Bai, T.; Xie, X.; Zhang, L.; Li, C.; Yuan, Y.; Chen, H.; Li, H.; Huang, H.; Tu, S.; Gong, F.; Liu, Y.; Wei, Y.; Dong, C.; Zhou, F.; Gu, X.; Xu, J.; Liu, Z.; Zhang, Y.; Li, H.; Shang, L.; Wang, K.; Li, K.; Zhou, X.; Dong, X.; Qu, Z.; Lu, S.; Hu, X.; Ruan, S.; Luo, S.; Wu, J.; Peng, L.; Cheng, F.; Pan, L.; Zou, J.; Jia, C.; Wang, J.; Liu, X.; Wang, S.; Wu, X.; Ge, Q.; He, J.; Zhan, H.; Qiu, F.; Guo, L.; Huang, C.; Jaki, T.; Hayden, F.G.; Horby, P.W.; Zhang, D.; Wang, C. A Trial of Lopinavir-Ritonavir in Adults Hospitalized with Severe Covid-19. N. Engl. J. Med., 2020, 382(19), 1787-99.

[74] Ford, N.; Vitoria, M.; Rangaraj, A.; Norris, S.L.; Calmy, A.; Doherty, M. Systematic Review of the Efficacy and Safety of Antiretroviral Drugs Against SARS, MERS or COVID-19: Initial Assessment. J. Int. AIDS Soc., 2020, 23(4), e25489.

[75] Guo, W.; Ming, F.; Dong, Y.; Zhang, Q.; Zhang, X.; Mo, P.; Feng, Y.; Liang, K. A Survey for COVID-19 among HIV/AIDS Patients in Two Districts of Wuhan, China. SSRN, 2020, https://dx.doi. org/10.2139/ssrn.3550029.

[76] Deeks, E.D. Darunavir/Cobicistat/Emtricitabine/Tenofovir Alafenamide: A Review in HIV-1 Infection. Drugs, 2018, 78(10), 1013-24.

[77] Mingming S.; Hongming Z.; Jiu-yan C.; Y., Y., Rational use and Pharmaceutical Care of Lopinavir/Ritonavir in the Treatment of Patients with Corona Virus Disease 2019. Chin. J. Hosp. Pharm., 2020, 40(7), 753-6.

[78] Stockman, L.J.; Bellamy, R.; Garner, P. SARS: Systematic Review of Treatment Effects. PLoS Med., 2006, 3(9), e343.

[79] Schneider, W.M.; Chevillotte, M.D.; Rice, C.M. InterferonStimulated Genes: A Complex Web of Host Defenses. Annu. Rev. Immunol., 2014, 32, 513-45.

[80] Sallard, E.; Lescure, F.X.; Yazdanpanah, Y.; Mentre, F.; PeifferSmadja, N. Type 1 Interferons as a Potential Treatment Against COVID-19. Antiviral Res., 2020, 178, 104791.

[81] Tan, E.L.C.; Ooi, E.E.; Lin, C.Y.; Tan, H.C.; Ling, A.E.; Lim, B.; Stanton, L.W. Inhibition of SARS Coronavirus Infection In Vitro with Clinically Approved Antiviral Drugs. Emerg. Infect. Dis. 2004, 10(4), 581-6.

[82] Zhou, Q.; Chen, V.; Shannon, C.P.; Wei, X.S.; Xiang, X.; Wang, X.; Wang, Z.H.; Tebbutt, S.J.; Kollmann, T.R.; Fish, E.N. Interferonalpha2b Treatment for COVID-19. Front. Immunol., 2020, 11, 1061.

[83] Zhang, H.; Kang, Z.; Gong, H.; Xu, D.; Wang, J.; Li, Z.; Cui, X.; Xiao, J.; Meng, T.; Zhou, W.J.B. The Digestive System is a Potential Route of 2019-nCov Infection: A Bioinformatics Analysis 
Based on Single-cell Transcriptomes. bioRxiv, 2020, https://doi org/10.1101/2020.01.30.927806.

[84] Huang, C.; Wang, Y.; Li, X.; Ren, L.; Zhao, J.; Hu, Y.; Zhang, L.; Fan, G.; Xu, J.; Gu, X.; Cheng, Z.; Yu, T.; Xia, J.; Wei, Y.; Wu, W.; Xie, X.; Yin, W.; Li, H.; Liu, M.; Xiao, Y.; Gao, H.; Guo, L.; Xie, J.; Wang, G.; Jiang, R.; Gao, Z.; Jin, Q.; Wang, J.; Cao, B. Clinical Features of Patients Infected with 2019 Novel Coronavirus in Wuhan, China. Lancet (London, England), 2020, 395(10223), 497-506.

[85] Costanzo, M.; De Giglio, M.A.R.; Roviello, G.N. SARS-CoV-2: Recent Reports on Antiviral Therapies Based on Lopinavir/ Ritonavir, Darunavir/Umifenovir, Hydroxychloroquine, Remdesivir, Favipiravir and Other Drugs for the Treatment of the New Coronavirus. Curr. Med. Chem., 2020, 27(27), 4536-41.

[86] Zhou, Y.; Fu, B.; Zheng, X.; Wang, D.; Zhao, C.; qi, Y.; Sun, R.; Tian, Z.; Xu, X.; Wei, H. Aberrant Pathogenic GM-CSF ${ }^{+}$T Cells and Inflammatory CD14 ${ }^{+} \mathrm{CD} 16^{+}$Monocytes in Severe Pulmonary Syndrome Patients of a New Coronavirus. bioRxiv 2020, 2020, 945576.

[87] Aziz, M.; Fatima, R.; Assaly, R. Elevated Interleukin-6 and Severe COVID-19: A Meta-Analysis. J. Med. Virol., 2020, 92(11), 2283-5. Sanders, J.M.; Monogue, M.L.; Jodlowski, T.Z.; Cutrell, J.B. Pharmacologic Treatments for Coronavirus Disease 2019 (COVID-19): A Review. JAMA, 2020, 323(18), 1824-36.

[89] Luo, S.; Yang. L.; Wang, C.; Liu, C.; Li, D. Clinical Observation of 6 Severe COVID-19 Patients Treated with Plasma Exchange or Tocilizumab. Zhejiang Da Xue Xue Bao Yi Xue Ban, 2020, 49(1), 227-31.

[90] Radbel, J.; Narayanan, N.; Bhatt, P.J. Use of Tocilizumab for COVID-19 Infection-induced Cytokine Release Syndrome: A Cautionary Case Report. Chest, 2020, 158(1), e15-9.

[91] Tian, X.; Li, C.; Huang, A.; Xia, S.; Lu, S.; Shi, Z.; Lu, L.; Jiang, S.; Yang, Z.; Wu, Y.; Ying, T. Potent Binding of 2019 Novel Coronavirus Spike Protein by a SARS Coronavirus-specific Human Monoclonal Antibody. Emerg. Microb. Infect., 2020, 9(1), $382-5$.

[92] Zheng, M.; Song, L. Novel Antibody Epitopes Dominate the Antigenicity of Spike Glycoprotein in SARS-CoV-2 Compared to SARS-CoV. Cell. Mol. Immunol., 2020,

[93] Russell, C.D.; Millar, J.E.; Baillie, J.K. Clinical Evidence Does not Support Corticosteroid Treatment for 2019-nCoV Lung Injury. Lancet (London, England), 2020, 395(10223), 473-5.

[94] Zhou, W.; Liu, Y.; Tian, D.; Wang, C.; Wang, S.; Cheng, J.; Hu, M.; Fang, M.; Gao, Y. Potential Benefits of Precise Corticosteroids Therapy for Severe 2019-nCoV Pneumonia. Signal Transduct. Target. Ther., 2020, 5(1), 18 .

[95] Xia, S.; Zhu, Y.; Liu, M.; Lan, Q.; Xu, W.; Wu, Y.; Ying, T.; Liu, S.; Shi, Z.; Jiang, S.; Lu, L. Fusion Mechanism of 2019-nCoV and Fusion Inhibitors Targeting HR1 Domain in Spike Protein. Cell. Mol. Immunol., 2020, 17(7), 765-7.

[96] Nguyen, T.M.; Zhang, Y.; Pandolfi, P.P. Virus Against Virus: A Potential Treatment for 2019-nCov (SARS-CoV-2) and Other RNA Viruses. Cell Res., 2020, 30(3), 189-90.

[97] Monteil, V.; Kwon, H.; Prado, P.; Hagelkruys, A.; Wimmer, R.A.; Stahl, M.; Leopoldi, A.; Garreta, E.; Del Pozo, C.H.; Prosper, F.; Romero, J.P.; Wirnsberger, G.; Zhang, H.; Slutsky, A.S.; Conder, R.; Montserrat, N.; Mirazimi, A.; Penninger, J.M. Inhibition of SARSCoV-2 Infections in Engineered Human Tissues Using ClinicalGrade Soluble Human ACE2. Cell, 2020, 181(4), 905-13.e7.

[98] Lei, C.; Qian, K.; Li, T.; Zhang, S.; Fu, W.; Ding, M.; Hu, S. Neutralization of SARS-CoV-2 Spike Pseudotyped Virus by Recombinant ACE2-Ig. Nat. Commun., 2020, 11(1), 2070.

[99] Carr, A.C.; Rosengrave, P.C.; Bayer, S.; Chambers, S.; Mehrtens, J.; Shaw, G.M. Hypovitaminosis C and Vitamin C Deficiency in Critically Ill Patients Despite Recommended Enteral and Parenteral Intakes. Crit. Care, 2017, 21(1), 300.

[100] Boretti, A.; Banik, B.K. Intravenous Vitamin C for Reduction of Cytokines Storm in Acute Respiratory Distress Syndrome. PharmaNutrition, 2020, 12, 100190.
[101] Hernandez, A.; Papadakos, P.J.; Torres, A.; Gonzalez, D.A.; Vives, M.; Ferrando, C.; Baeza, J. Two Known Therapies Could be Useful as Adjuvant Therapy in Critical Patients Infected by COVID-19. Rev. Esp. Anestesiol. Reanim., 2020, 67(5), 245-52.

[102] Iii, A.A.F.; Kim, C.; Lepler, L.; Malhotra, R.; Debesa, O.; Natarajan, R.; Fisher, B. J.; Syed, A.; DeWilde, C.; Priday, A.; Kasirajan, V. Intravenous Vitamin $\mathrm{C}$ as Adjunctive Therapy for Enterovirus/Rhinovirus Induced Acute Respiratory Distress Syndrome. World J. Crit. Care Med, 2017, 6(1), 85-90.

[103] Linjie, H.; Fuchao, C.; Xueqiang, J.; Zhihao, L.; Wan, W. Clinical characteristics and therapy of novel corona virus pneumonia: 71 cases retrospective analysis. Central South Pharmacy 2020, 18(5), 739-42.

[104] Hantoushzadeh, S.; Norooznezhad, A.H. Inappropriate Antibiotic Consumption as a Possible Cause of Inflammatory Storm and Septic Shock in Patients Diagnosed with Coronavirus Disease 2019 (COVID-19). Arch. Med. Res., 2020, 51(4), 347-348.

[105] Caly, L.; Druce, J.D.; Catton, M.G.; Jans, D.A.; Wagstaff, K.M. The FDA-Approved Drug Ivermectin Inhibits the Replication of SARS-CoV-2 In Vitro. Antiviral Res., 2020, 178, 104787.

[106] Gharebaghi, R.; Heidary, F.; Moradi, M.; Parvizi, M. Metronidazole; a Potential Novel Addition to the COVID-19 Treatment Regimen. Arch. Acad. Emerg. Med., 2020, 8(1), e40.

[107] Hoffmann, M.; Kleine-Weber, H.; Schroeder, S.; Krüger, N.; Herrler, T.; Erichsen, S.; Schiergens, T.S.; Herrler, G.; Wu, N.H.; Nitsche, A.; Müller, M.A.; Drosten, C.; Pöhlmann, S. SARS-CoV-2 Cell Entry Depends on ACE2 and TMPRSS2 and is Blocked by a Clinically Proven Protease Inhibitor. Cell, 2020, 181(2), 271-80.e8.

[108] Rosa, S.G.V.; Santos, W.C. Clinical Trials on Drug Repositioning for COVID-19 Treatment. Rev. Pan Salud Publica, 2020, 44, e40.

[109] Maggio, R.; Corsini, G.U. Repurposing the Mucolytic Cough Suppressant and TMPRSS2 Protease Inhibitor Bromhexine for the Prevention and Management of SARS-CoV-2 Infection. Pharmacol. Res., 2020, 157, 104837.

[110] Clark, W.F.; Huang, S.S. Introduction to Therapeutic Plasma Exchange. Transfus. Apher. Sci., 2019, 58(3), 228-9.

[111] Harzallah, I.; Debliquis, A.; Drenou, B. Lupus Anticoagulant is Frequent in Patients with Covid-19. J. Thromb. Haemost., 2020, 18(8), 2064-5.

[112] Ma, J.; Xia, P.; Zhou, Y.; Liu, Z.; Zhou, X.; Wang, J.; Li, T.; Yan, X.; Chen, L.; Zhang, S.; Qin, Y.; Li, X. Potential Effect of Blood Purification Therapy in Reducing Cytokine Storm as a Late Complication of Critically Ill COVID-19. Clin. Immunol., 2020, 214,108408

[113] Shi, H.; Zhou, C.; He, P.; Huang, S.; Duan, Y.; Wang, X.; Lin, K.; Zhou, C.; Zhang, X.; Zha, Y. Successful Treatment of Plasma Exchange Followed by Intravenous Immunogloblin in a Critically Ill Patient with 2019 Novel Coronavirus Infection. Int. J. Antimicrob. Agents, 2020, 56(2), 105974.

[114] Bloch, E.M.; Shoham, S.; Casadevall, A.; Sachais, B.S.; Shaz, B.; Winters, J.L.; van Buskirk, C.; Grossman, B.J.; Joyner, M.; Henderson, J.P.; Pekosz, A.; Lau, B.; Wesolowski, A.; Katz, L.; Shan, H.; Auwaerter, P.G.; Thomas, D.; Sullivan, D.J.; Paneth, N.; Gehrie, E.; Spitalnik, S.; Hod, E.; Pollack, L.; Nicholson, W.T.; Pirofski, L.A.; Bailey, J.A.; Tobian, A.A. Deployment of Convalescent Plasma for the Prevention and Treatment of COVID-19. J. Clin. Invest., 2020, 130(6), 2757-65.

[115] Ahn, J.Y.; Sohn, Y.; Lee, S.H.; Cho, Y.; Hyun, J.H.; Baek, Y.J.; Jeong, S.J.; Kim, J.H.; Ku, N.S.; Yeom, J.S.; Roh, J.; Ahn, M.Y.; Chin, B.S.; Kim, Y.S.; Lee, H.; Yong, D.; Kim, H.O.; Kim, S.; Choi, J.Y. Use of Convalescent Plasma Therapy in Two COVID-19 Patients with Acute Respiratory Distress Syndrome in Korea. J. Korean Med. Sci., 2020, 35(14), e149.

[116] Ye, M.; Fu, D.; Ren, Y.; Wang, F.; Wang, D.; Zhang, F.; Xia, X.; Lv, T. Treatment with Convalescent Plasma for COVID-19 Patients in Wuhan, China. J. Med. Virol., 2020, 92(10), 1890-901.

[117] Zhang, B.; Liu, S.; Tan, T.; Huang, W.; Dong, Y.; Chen, L.; Chen, Q.; Zhang, L.; Zhong, Q.; Zhang, X.; Zou, Y.; Zhang, S. Treatment With Convalescent Plasma for Critically Ill Patients 
With SARS-CoV-2 Infection. Chest, 2020, 158(1), e9-13.

[118] Zeng, Q.L.; Yu, Z.J.; Gou, J.J.; Li, G.M.; Ma, S.H.; Zhang, G.F.; Xu, J.H.; Lin, W.B.; Cui, G.L.; Zhang, M.M.; Li, C.; Wang, Z.S.; Zhang, Z.H.; Liu, Z.S. Effect of Convalescent Plasma Therapy on Viral Shedding and Survival in COVID-19 Patients. J. Infect. Dis., 2020, 222(1), 38-43.

[119] Calder, P.C.; Carr, A.C.; Gombart, A.F.; Eggersdorfer, M. Optimal Nutritional Status for a Well-Functioning Immune System is an Important Factor to Protect against Viral Infections. Nutrients, 2020, 12(4), 1181.

[120] Zhang, J.; Zeng, H.; Gu, J.; Li, H.; Zheng, L.; Zou, Q. Progress and Prospects on Vaccine Development against SARS-CoV-2. Vaccines (Basel), 2020, 8(2), 153.

[121] Ahn, D.G.; Shin, H.J.; Kim, M.H.; Lee, S.; Kim, H.S.; Myoung, J.; Kim, B.T.; Kim, S.J. Current Status of Epidemiology, Diagnosis, Therapeutics, and Vaccines for Novel Coronavirus Disease 2019 (COVID-19). J. Microbiol. Biotechnol., 2020, 30(3), 313-24.

[122] Feng-Cai, Z.; Li, Y.H.; Guan, X.H.; Hou, L.H.; Wang, W.J.; Li, J.X.; Wu, S.P.; Wang, B.S.; Wang, Z.; Wang, L.; Jia, S.Y.; Jiang, H.D.; Wang, L.; Jiang, T.; Hu, Y.; Gou, J.B.; Xu, S.B.; Xu, J.J.; Wang, X.W.; Wang, W.; Chen, W. Safety, Tolerability, and Immunogenicity of a Recombinant Adenovirus Type-5 Vectored COVID-19 Vaccine: A Dose-escalation, Open-label, Nonrandomised, First-in-human Trial. Lancet, 2020, 395(10240), $1845-54$

[123] Folegatti, P.M.; Ewer, K.J.; Aley, P.K.; Angus, B.; Becker, S.; BelijRammerstorfer, S.; Bellamy, D.; Bibi, S.; Bittaye, M.; Clutterbuck, E.A.; Dold, C.; Faust, S.N.; Finn, A.; Flaxman, A.L.; Hallis, B.; Heath, P.; Jenkin, D.; Lazarus, R.; Makinson, R.; Minassian, A.M.; Pollock, K.M.; Ramasamy, M.; Robinson, H.; Snape, M.; Tarrant, R.; Voysey, M.; Green, C.; Douglas, A.D.; Hill, A.V.S.; Lambe, T.; Gilbert, S.C.; Pollard, A.J.; Aboagye, J.; Adams, K.; Ali, A.; Allen, E.; Allison, J.L.; Anslow, R.; Arbe-Barnes, E.H.; Babbage, G.; Baillie, K.; Baker, M.; Baker, N.; Baker, P.; Baleanu, I.; Ballaminut, J.; Barnes, E.; Barrett, J.; Bates, L.; Batten, A.; Beadon, K.; Beckley, R.; Berrie, E.; Berry, L.; Beveridge, A.; Bewley, K.R.; Bijker, E.M.; Bingham, T.; Blackwell, L.; Blundell, C.L.; Bolam, E.; Boland, E.; Borthwick, N.; Bower, T.; Boyd, A.; Brenner, T.; Bright, P.D.; Brown-O'Sullivan, C.; Brunt, E.; Burbage, J.; Burge, S.; Buttigieg, K.R.; Byard, N.; Puig, I.C.; Calvert, A.; Camara, S.; Cao, M.; Cappuccini, F.; Carr, M.; Carroll, M.W.; Carter, V.; Cathie, K.; Challis, R.J.; Charlton, S.; Chelysheva, I.; Cho, J.S.; Cicconi, P.; Cifuentes, L.; Clark, H.; Clark, E.; Cole, T.; ColinJones, R.; Conlon, C.P.; Cook, A.; Coombes, N.S.; Cooper, R.; Cosgrove, C.A.; Coy, K.; Crocker, W.E.M.; Cunningham, C.J.; Damratoski, B.E.; Dando, L.; Datoo, M.S.; Davies, H.; De Graaf, H.; Demissie, T.; Di Maso, C.; Dietrich, I.; Dong, T.; Donnellan, F.R.; Douglas, N.; Downing, C.; Drake, J.; Drake-Brockman, R.; Drury, R.E.; Dunachie, S.J.; Edwards, N.J.; Edwards, F.D.L.; Edwards, C.J.; Elias, S.C.; Elmore, M.J.; Emary, K.R.W.; English, M.R.; Fagerbrink, S.; Felle, S.; Feng, S.; Field, S.; Fixmer, C.; Fletcher, C.; Ford, K.J.; Fowler, J.; Fox, P.; Francis, E.; Frater, J.; Furze, J.; Fuskova, M.; Galiza, E.; Gbesemete, D.; Gilbride, C.; Godwin, K.; Gorini, G.; Goulston, L.; Grabau, C.; Gracie, L.; Gray, Z.; Guthrie, L.B.; Hackett, M.; Halwe, S.; Hamilton, E.; Hamlyn, J.; Hanumunthadu, B.; Harding, I.; Harris, S.A.; Harris, A.; Harrison, D.; Harrison, C.; Hart, T.C.; Haskell, L.; Hawkins,
S.; Head, I.; Henry, J.A.; Hill, J.; Hodgson, S.H.C.; Hou, M.M.; Howe, E.; Howell, N.; Hutlin, C.; Ikram, S.; Isitt, C.; Iveson, P.; Jackson, S.; Jackson, F.; James, S.W.; Jenkins, M.; Jones, E.; Jones, K.; Jones, C.E.; Jones, B.; Kailath, R.; Karampatsas, K.; Keen, J.; Kelly, S.; Kelly, D.; Kerr, D.; Kerridge, S.; Khan, L.; Khan, U.; Killen, A.; Kinch, J.; King, T.B.; King, L.; King, J.; Kingham-Page, L.; Klenerman, P.; Knapper, F.; Knight, J.C.; Knott, D.; Koleva, S.; Kupke, A.; Larkworthy, C.W.; Larwood, J.P.J.; Laskey, A.; Lawrie, A.M.; Lee, A.; Ngan Lee, K.Y.; Lees, E.A.; Legge, H.; Lelliott, A.; Lemm, N.M.; Lias, A.M.; Linder, A.; Lipworth, S.; Liu, X.; Liu, S.; Lopez Ramon, R.; Lwin, M.; Mabesa, F.; Madhavan, M.; Mallett, G.; Mansatta, K.; Marcal, I.; Marinou, S.; Marlow, E.; Marshall, J.L.; Martin, J.; McEwan, J.; McInroy, L.; Meddaugh, G.; Mentzer, A.J.; Mirtorabi, N.; Moore, M.; Moran, E.; Morey, E.; Morgan, V.; Morris, S.J.; Morrison, H.; Morshead, G.; Morter, R.; Mujadidi, Y. F.; Muller, J.; Munera-Huertas, T.; Munro, C.; Munro, A.; Murphy, S.; Munster, V.J.; Mweu, P.; Noé, A.; Nugent, F.L.; Nuthall, E.; O’Brien, K.; O'Connor, D.; Oguti, B.; Oliver, J.L.; Oliveira, C.; O'Reilly, P.J.; Osborn, M.; Osborne, P.; Owen, C.; Owens, D.; Owino, N.; Pacurar, M.; Parker, K.; Parracho, H.; Patrick-Smith, M.; Payne, V.; Pearce, J.; Peng, Y.; Peralta Alvarez, M.P.; Perring, J.; Pfafferott, K.; Pipini, D.; Plested, E.; Pluess-Hall, H.; Pollock, K.; Poulton, I.; Presland, L.; Provstgaard-Morys, S.; Pulido, D.; Radia, K.; Lopez, F.R.; Rand, J.; Ratcliffe, H.; Rawlinson, T.; Rhead, S.; Riddell, A.; Ritchie, A.J.; Roberts, H.; Robson, J.; Roche, S.; Rohde, C.; Rollier, C.S.; Romani, R.; Rudiansyah, I.; Saich, S.; Sajjad, S.; Salvador, S.; Sanchez Riera, L.; Sanders, H.; Sanders, K.; Sapaun, S.; Sayce, C.; Schofield, E.; Screaton, G.; Selby, B.; Semple, C.; Sharpe, H.R.; Shaik, I.; Shea, A.; Shelton, H.; Silk, S.; Silva-Reyes, L.; Skelly, D.T.; Smee, H.; Smith, C.C.; Smith, D.J.; Song, R.; Spencer, A.J.; Stafford, E.; Steele, A.; Stefanova, E.; Stockdale, L.; Szigeti, A.; Tahiri-Alaoui, A.; Tait, M.; Talbot, H.; Tanner, R.; Taylor, I.J.; Taylor, V.; Te Water Naude, R.; Thakur, N.; Themistocleous, Y.; Themistocleous, A.; Thomas, M.; Thomas, T. M.; Thompson, A.; Thomson-Hill, S.; Tomlins, J.; Tonks, S.; Towner, J.; Tran, N.; Tree, J.A.; Truby, A.; Turkentine, K.; Turner, C.; Turner, N.; Turner, S.; Tuthill, T.; Ulaszewska, M.; Varughese, R.; Van Doremalen, N.; Veighey, K.; Verheul, M.K.; Vichos, I.; Vitale, E.; Walker, L.; Watson, M.E.E.; Welham, B.; Wheat, J.; White, C.; White, R.; Worth, A.T.; Wright, D.; Wright, S.; Yao, X.L.; Yau, Y. Safety and Immunogenicity of the ChAdOx1 nCoV-19 Vaccine Against SARS-CoV-2: A Preliminary Report of a Phase 1/2, Single-Blind, Randomised Controlled Trial. Lancet, 2020, 396(10249), 467-78.

[124] Logunov, D.Y.; Dolzhikova, I.V.; Zubkova, O.V.; Tukhvatullin, A.I.; Shcheblyakov, D.V.; Dzharullaeva, A.S.; Grousova, D.M.; Erokhova, A.S.; Kovyrshina, A.V.; Botikov, A.G.; Izhaeva, F.M.; Popova, O.; Ozharovskaya, T.A.; Esmagambetov, I.B.; Favorskaya, I.A.; Zrelkin, D.I.; Voronina, D.V.; Shcherbinin, D.N.; Semikhin, A.S.; Simakova, Y.V.; Tokarskaya, E.A.; Lubenets, N.L.; Egorova, D.A.; Shmarov, M.M.; Nikitenko, N.A.; Morozova, L.F.; Smolyarchuk, E.A.; Kryukov, E.V.; Babira, V.F.; Borisevich, S.V.; Naroditsky, B.S.; Gintsburg, A.L. Safety and Immunogenicity of an rAd26 and rAd5 Vector-based Heterologous Prime-boost COVID-19 Vaccine in Two Formulations: Two Open, Non-randomised Phase 1/2 Studies from Russia. Lancet, 2020, 396(10255), 887-97. 